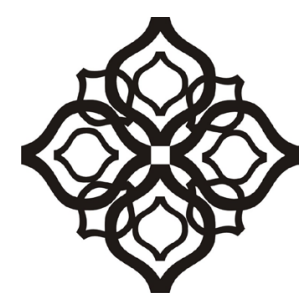

Shirkah

Journal of Economics and Business 


\section{Shirkah}

Journal of Economics and Business

Vol. 4, No. 1, January-April 2019

ISSN: 2503-4235 (p); 2503-4243 (e)

\section{Editor in Chief}

Fitri Wulandari

\section{Managing Editor}

Jasanta Peranginangin

\section{Editorial Boards}

Abdul Azim Islahi, Islamic Economics Institute, King Abdulaziz University, Saudi Arabia Abu Umar Faruq Ahmad, UBD School of Business and Economics Universiti, Brunei Darussalam Cedomir Nestorovic, ESSEC Business School Asia Pacific, Singapore

Fitri Wulandari, Faculty of Islamic Economics and Business, IAIN Surakarta, Indonesia Johan Fischer,

Department of Social Sciences and Business Roskilde Universitetscenter, Denmark Muhamed Zulkhibri, Islamic Research and Training Institute, Islamic Development Bank, Saudi Arabia M. Kabir Hassan,

Department of Economics and Finance, University of New Orleans, United States Musa Asy'arie,

Faculty of Islamic Economics and Business, IAIN Surakarta, Indonesia Nunung Nurul Hidayah, Aston Business School, Aston University, Birmingham, United Kingdom Saim Kayadibi,

Department of Economics, Kulliyyah of Economics and Management Science, International Islamic University Malaysia, Malaysia 
Shaikh M Ghazanfar,

Departement of Economics, University of Idaho, Russian Federation

Sigit S. Wibowo,

Department of Management, Faculty of Economics and Business, Universitas Indonesia, Indonesia

Vihang R. Errunza,

Desmarais Global Finance Research Centre, Desautels Faculty and Management, McGill University, Canada

\section{Assistant to Editor \\ M. Endy Saputro \\ M. Zainal Anwar}

Shirkah Journal of Economics and Business is a peer-reviewed journal published three times a year (January-April, May-August and September-December) by Faculty of Islamic Economics and Business, Institut Agama Islam Negeri (IAIN) Surakarta Central Java, Indonesia. The main objective of Shirkah is to offer an academic space of exchange ideas and initiate the increase number of qualified article produced by postgraduate students, practitioners and academicians.

\section{Editorial Office}

Ruang Jurnal Shirkah

Lantai Dasar, Sayap Barat, Fakultas Ekonomi dan Bisnis Islam, IAIN Surakarta

Jln. Pandawa No. 1, Kartasura, Sukoharjo, Jawa Tengah Kode Pos. 57168

Phone (+62271) 781516 Fax: (+62271)782336

E-mail: shirkahjournal@iainsurakarta.ac.id; shirkahiainsurakarta@gmail.com

Website: http://shirkah.or.id/ 


\section{Shirkah}

Journal of Economics and Business

Vol. 4, No. 1, January-April 2019

ISSN: 2503-4235 (p); 2503-4243 (e)

\section{Table of Contents}

\section{Articles}

Datien Eriska Utami

Identifying Financial and Non-Financial Factors as

the Determinant of Sukuk Rating in Indonesia

JM Muslimin

Halal Product Guarantee in

Indonesia Regulation and Social Inclusion

Isnan Indriati

Muh. Rudi Nugroho

Kuznet's Hypothesis and Ibn Khaldun's Socio-Economic Dimensions

Lucky Nugroho

Ahmad Badawi

Nurul Hidayah

Indonesia Islamic Bank Profitability 2010-2017

Aam Slamet Rusydiana

Lina Marlina

Lina Nugraha Rani

Malmquist Productivity Index on Islamic Economics and

Finance Research

Ahmad Farras Adibuddin

Doddy Setiawan

Bambang Sutopo

The Recent Development of Islamic Economic Studies in Indonesia 


\title{
The Recent Development of Islamic Economic Studies in Indonesia
}

\author{
Ahmad Farras Adibuddin \\ Faculty of Economic and Business, Universitas Sebelas Maret \\ ahmadfarras92@gmail.com \\ Doddy Setiawan \\ Faculty of Economic and Business, Universitas Sebelas Maret \\ doddy.setiawan@gmail.com \\ Bambang Sutopo \\ Faculty of Economic and Business, Universitas Sebelas Maret \\ bambang.sutopo@gmail.com
}

\begin{abstract}
This study outlines the recent development of Islamic economics in Indonesia. The data has been gathered from articles on Islamic economics published in the select national accredited journals in Indonesia from 2004 - 2017, consisting of 184 articles. This study has applied the field method chart as suggested by Hesford. We have classified these articles based on the field of research, the research topic, and its method. This study finds that there is an increase number of articles on Islamic economics in Indonesia published on national-accredited journals. These selected articles mostly discussed such topics relating to the banking issues.
\end{abstract}

Keywords: Islamic economics, bibliography, analitycal method, literature studies, survey method.

\section{Introduction}

The history of Islamic economics began when Islam came for the first time to Indonesia through trade channel by some merchants from Persia, Gujarat, Yemen, China and some other countries. Meanwhile, the development of Islamic economics in modern era in Indonesia has been 
recognized since the establishment of Bank Mualamat in 1992. In turn, it came various laws supporting the economic system, such as Law No 7 of 1992 on banking as amended on Law no 10 of 1998. Subsequently, several laws have emerged as a form of government support for the progress of Islamic economics in Indonesia. The economic crisis in Indonesia in early 1997 had a major impact on banking institutions that ended with liquidation in several banks. However, this financial tsunami did not work on Islamic banks. Islamic banks has been still standing strong and even growing rapidly. The rapid development of Islamic economics must be addressed carefully and thoroughly. The researchers in Indonesia attempt to give new ideas on the Islamic economics in Indonesia. The results of those thoughts are various and published on scientific journals in Indonesia.

This study continues such previous study as Hesford et al (2007) and Suprianto and Setiawan (2017) that investigate the recent development of management accounting and earnings management, respectively. We focus on development of Islamic economics in Indonesian context. Indonesia has been the largest Muslim population in the world with a socio-cultural society inspired by Islamic values and the fifth country with the world's strongest economy. This study has gathered 184 articles on Islamic economics in nine accredited journals in Indonesia for 14 years (from 2004 to 2017) applying two approaches: charting the field and analyzing the community. These two approaches have been used to outline the development of Islamic economics in Indonesia from various aspects. This research attests the development of Islamic economics in Indonesia and promotes a perspective for further research.

\section{Research Method}

This research has employed method by Hesford et al (2007), namely charting the field. Using this approach, we attempt to select some research 
articles on Islamic economics published in nine journals: Indonesian Accounting \& Auditing Journal (JAAI), Indonesian Accounting \& Financing Journal (JAKI), Multi Paradigm Accounting Journal (JAMAL), Financing and Banking Journal (JKP), Iqtishadia, Economic and Development of Indonesia Journal (JEPI), Journal of Economics, Business and Accountancy of Ventura, Signifikan and Al Iqtishad. In turn, it has been grouped based on its topic, and its method. These journals has been selected in accordance to the criteria: these journals have been accredited in 2017, and it can be accessed online. We select systematically all articles published in each journal, related to Islamic economics in Indonesia.

\section{Result and Discussion}

We select the 14-year period between 2004 to 2017 since during this period, the development on Islamic economics in Indonesia undergoes a lot of progress as can be seen on table 1 . The selection process generates 184 articles. We record bibliographic data of the article which consists of journal name, the year of publication, the page, the name of the researcher, institutional affiliation at the time of publication, as well as the reference list of each article. Since offline articles are not available, we do not insert them for the selection. On the table 2, the sample description can be seen in a whole form (from 2004 to 2017). There is one journal which dominates the research on Islamic economics, that is Al-Iqtishad, by $37,5 \%$; meanwhile JKP by $25 \%$, Iqtishadia by $11,9 \%$, JAAI by $6,5 \%$, Signifikan by $4,9 \%$, Ventura by $4,4 \%$, JAKI by $3,8 \%$, JAMAL by $3,8 \%$ and the lowest is JEPI by $2,2 \%$. In sum, there are only four articles related to Islamic Economics.

Based on table 2, there has been an increasing number of articles published in accredited journals in Indonesia, as can be seen from two period of observation groups; the first period lies between 2004 to 2010 
and period 2 range between 2011 to 2017 . The result shows an increase from 31 articles to 153 articles, or around $400 \%$.

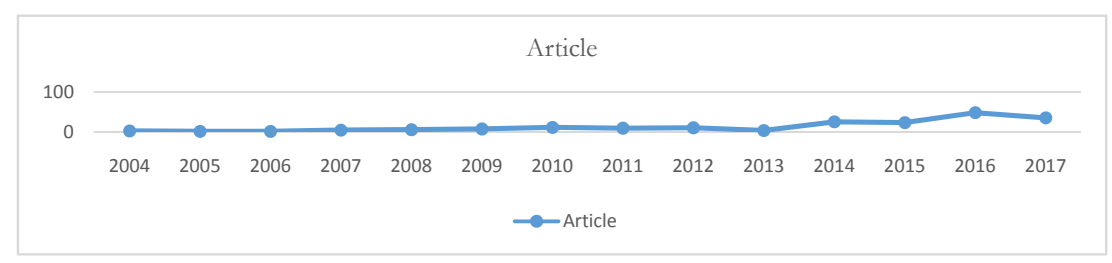

Table 1. Islamic Economics Research Development

Table 2. Sample Statistic

\begin{tabular}{|l|c|c|c|}
\hline \multirow{2}{*}{ Journal Name } & 2004 to 2017 & 2004 to 2010 & 2011 to 2017 \\
\cline { 2 - 4 } & $\begin{array}{c}\text { Article } \\
\text { (percentage) }\end{array}$ & $\begin{array}{c}\text { Article } \\
\text { (percentage) }\end{array}$ & $\begin{array}{c}\text { Article } \\
\text { (percentage) }\end{array}$ \\
\hline JAAI & $12(6,5 \%)$ & 7 & 5 \\
\hline JAKI & $7(3,8 \%)$ & 3 & 4 \\
\hline AL-IQTISHAD & $69(37,5 \%)$ & 0 & 70 \\
\hline JAMAL & $7(3,8 \%)$ & 1 & 6 \\
\hline JKP & $46(25 \%)$ & 16 & 30 \\
\hline JEPI & $4(2,2 \%)$ & 4 & 0 \\
\hline Ventura & $8(4,4 \%)$ & 0 & 22 \\
\hline IQTISHADIA & $22(11,9 \%)$ & 0 & 9 \\
\hline Signifikan & $9(4,9 \%)$ & 0 & 153 \\
\hline Total & 184 & 31 & 8 \\
\hline
\end{tabular}

The article classification on Islamic economics has been grouped into 5 fields: banking, insurance, capital market, zakat (payment made annually under Islamic law on certain kinds of property and used for charitable), infaq (spending wealth for a certain purpose as guided by Islam), and sadaqa (a gift of property to indigent people). Based on table 3 , we can see the research focus which have been conducted. Mostly the researches have mainly focused on banking (52,7\%), followed by other 
fields $(25,5 \%)$ such as capital market (14,1\%), zakat, infaq, sadaqa (4,3\%) and insurance $(3,3 \%)$. The research opportunity outside of banking field has still widely opened, especially the research in the field of insurance may be developed since there are only six articles in the 14-year observation.

Table 3. Article Classification Based on Field Focus

\begin{tabular}{|l|c|c|c|}
\hline \multirow{2}{*}{ Field Focus } & $\mathbf{2 0 0 4}$ to 2017 & 2004 to 2010 & 2011 to 2017 \\
\cline { 2 - 4 } & $\begin{array}{c}\text { Article } \\
\text { (Percentage) }\end{array}$ & $\begin{array}{c}\text { Article } \\
\text { (Percentage) }\end{array}$ & $\begin{array}{c}\text { Article } \\
\text { (Percentage) }\end{array}$ \\
\hline Banking & $97(52,7 \%)$ & 19 & 78 \\
\hline Insurance & $6(3,3 \%)$ & 0 & 6 \\
\hline Capital Market & $26(14,1 \%)$ & 4 & 22 \\
\hline Zakat, Infaq, Sadaqa & $8(4,3 \%)$ & 0 & 8 \\
\hline Other & $47(25,5 \%)$ & 8 & 39 \\
\hline Total & 184 & 31 & 153 \\
\hline
\end{tabular}

From the table 4, it shows that such articles on Islamic economics have focused on product disclosure, system/ regulation and so forth. It displays that there are still numerous topics related to Islamic economics which has been rarely examined. Table 4.1 demonstrates that on banking field research, the topic has mainly discussed on the disclosure by 46 articles $(47,4 \%)$, which has been seen from the increase number of research articles from period of 2004-2010. There are only 19 articles which later upsurge in the next period to 78 articles. However, there are many other topics outside of banking field which can be examined, for instance, topic related to the banking system/regulation.

Table 4.2 depicts that the topics on insurance is still very limited. Over the last 6 years, there were only six articles in which, $50 \%$ of the number of the research on insurance field has focused on disclosure topics. Table 4.3 illustrates that the field of capital market has focused on the disclosure topic. It can be seen from 12 articles (46,2\%) of the total 26 
articles related to the capital market. In other words, it invites such other topics to discuss in this field. From table 4.4, discussion topic on zakat, infaq and sadaqa mostly examines related to their products. It is shown around 50\% which are related to the topics and related issues.

Table 4.5 indicates that there are many research opportunities outside of the fields studied above. Meanwhile the next table 4.5 displays the topic discussed by other fields which has prioritized on disclosure as much as $38,3 \%$, followed by other topics of $34 \%$, system/regulation of $14,9 \%$, and product of $12,8 \%$. From the classification, it is apparent that most of articles of Islamic economics research in Indonesia in various fields have emphasized on the disclosure topic, which later followed by topics related to product and system/regulation. Thus, there are many topics related to Islamic economics in various fields which are very likely to further study.

Table 4.1 Banking Field

\begin{tabular}{|l|c|c|c|}
\hline \multirow{2}{*}{ Topic } & 2004 to 2017 & 2004 to 2010 & 2011 to 2017 \\
\cline { 2 - 4 } & $\begin{array}{c}\text { Article } \\
\text { (percentage) }\end{array}$ & $\begin{array}{c}\text { Article } \\
\text { (percentage) }\end{array}$ & $\begin{array}{c}\text { Article } \\
\text { (percentage) }\end{array}$ \\
\hline Disclosure & $46(47,4 \%)$ & 5 & 41 \\
\hline Product & $12(12,4 \%)$ & 5 & 7 \\
\hline System/Regulation & $9(9,3 \%)$ & 2 & 7 \\
\hline others & $30(30,9 \%)$ & 7 & 23 \\
\hline Total & 97 & 19 & 78 \\
\hline
\end{tabular}

Table 4.2 Insurance Field

\begin{tabular}{|l|c|c|c|}
\hline \multirow{2}{*}{ Topic } & 2004 to 2017 & 2004 to 2010 & 2011 to 2017 \\
\cline { 2 - 4 } & $\begin{array}{c}\text { Article } \\
\text { (percentage) }\end{array}$ & $\begin{array}{c}\text { Article } \\
\text { (percentage) }\end{array}$ & $\begin{array}{c}\text { Article } \\
\text { (percentage) }\end{array}$ \\
\hline Disclosure & $3(50 \%)$ & - & 3 \\
\hline Product & $2(33,3 \%)$ & - & 2 \\
\hline
\end{tabular}




\begin{tabular}{|l|c|c|c|}
\hline System/Regulation & $1(16,7 \%)$ & - & 1 \\
\hline Others & - & - & - \\
\hline Total & 6 & - & 6 \\
\hline
\end{tabular}

Table 4.3 Capital Market Field

\begin{tabular}{|l|c|c|c|}
\hline \multirow{2}{*}{ Topic } & 2004 to 2017 & 2004 to 2010 & 2011 to 2017 \\
\cline { 2 - 4 } & $\begin{array}{c}\text { Article } \\
\text { (percentage) }\end{array}$ & $\begin{array}{c}\text { Article } \\
\text { (percentage) }\end{array}$ & $\begin{array}{c}\text { Article } \\
\text { (percentage) }\end{array}$ \\
\hline Disclosure & $12(46,2 \%)$ & 1 & 11 \\
\hline Product & $10(38,5 \%)$ & 2 & 8 \\
\hline System/Regulation & $1(3,8 \%)$ & 1 & - \\
\hline Others & $3(11,5 \%)$ & - & 3 \\
\hline Total & 26 & 4 & 22 \\
\hline
\end{tabular}

Table 4.4 Zakat, Infaq, Sodaqa Field

\begin{tabular}{|l|c|c|c|}
\hline \multirow{1}{*}{ Topic } & 2004 to 2017 & 2004 to 2010 & 2011 to 2017 \\
\cline { 2 - 4 } & $\begin{array}{c}\text { Article } \\
\text { (percentage) }\end{array}$ & $\begin{array}{c}\text { Article } \\
\text { (percentage) }\end{array}$ & $\begin{array}{c}\text { Article } \\
\text { (percentage) }\end{array}$ \\
\hline Disclosure & $2(25 \%)$ & - & 2 \\
\hline Product & $4(50 \%)$ & - & 4 \\
\hline System/Regulation & - & - & - \\
\hline others & $2(25 \%)$ & - & 2 \\
\hline Total & 8 & - & 8 \\
\hline
\end{tabular}

Table 4.5 Other Fields

\begin{tabular}{|l|c|c|c|}
\hline \multirow{2}{*}{ Topic } & 2004 to 2017 & 2004 to 2010 & 2011 to 2017 \\
\cline { 2 - 4 } & $\begin{array}{c}\text { Article } \\
\text { (percentage) }\end{array}$ & $\begin{array}{c}\text { Article } \\
\text { (percentage) }\end{array}$ & $\begin{array}{c}\text { Article } \\
\text { (percentage) }\end{array}$ \\
\hline Disclosure & $18(38,3 \%)$ & 2 & 16 \\
\hline Product & $6(12,8 \%)$ & 4 & 2 \\
\hline System/Regulation & $7(14,9 \%)$ & 2 & 5 \\
\hline Others & $16(34 \%)$ & - & 16 \\
\hline Total & 47 & 8 & 39 \\
\hline
\end{tabular}


Based on research method applied by such researchers, it can be classified based on three research methods: survey method, analytical method, and literature review method. Furthermore, as shown table 5, it shows that for 14 years, the research method used in Indonesia is analytical method, by around 58,2\% (107 articles). Meanwhile the number of article using literature review method is by around 30,4\% (56 articles), and that of using survey is by around $11,4 \%$ (21 articles). Table 5 also shows on the first period, the analysis strategy has been dominated by literature review research method, by $46,7 \%$ (14 articles); analytical method by $43,33 \%$ (13 articles); and survey by $10 \%$ ( 3 articles). In the second period, analytical research articles have significantly increased by 600\% (from 13 to 94 articles). Meanwhile, articles-based survey has surged by 500\% (3 to 18 articles) and articles-based literature review has the same trend by $200 \%$ (from 14 to 42 articles). To sum, the most dominant research method has been the analytical method.

Table 6 expresses the journal characteristics compared to the research method. Analytical research method has been employed in all journals, except that in JAMAL. Moreover, literature review method has been utilized in all journals, except in JEPI. The journal articles on Islamic economics which have employed survey are limited and published in such journals as Signifikan (1 article), JAAI (2 articles), JKP (5 articles), Iqtishadia (5 articles), and Al-Iqtishad (8 articles). Meanwhile, the journal articles which have applied analytical method, literature review and survey are varied published in Al-Iqtishad by 43\% (46 of 107 articles), 28\% (15 of 56 articles) and $38,1 \%$ (8 of 21 articles), respectively. 
Table 5. Article Classification Based on Research Method

\begin{tabular}{|l|c|c|c|}
\hline \multirow{2}{*}{ Topic } & $\mathbf{2 0 0 4}$ to 2017 & $\mathbf{2 0 0 4}$ to 2010 & $\mathbf{2 0 1 1}$ to $\mathbf{2 0 1 7}$ \\
\cline { 2 - 4 } & $\begin{array}{c}\text { Article } \\
\text { (percentage) }\end{array}$ & $\begin{array}{c}\text { Article } \\
\text { (percentage) }\end{array}$ & $\begin{array}{c}\text { Article } \\
\text { (percentage) }\end{array}$ \\
\hline Analytical & $107(58,2 \%)$ & $13(43,3 \%)$ & $94(61 \%)$ \\
\hline Review & $56(30,4 \%)$ & $14(46,7 \%)$ & $42(27,3 \%)$ \\
\hline Survey & $21(11,4 \%)$ & $3(10 \%)$ & $18(11,7 \%)$ \\
\hline Total & 184 & 30 & 154 \\
\hline
\end{tabular}

Table 6. Journal Classification Based on Research Method

\begin{tabular}{|l|c|c|c|}
\hline \multirow{2}{*}{ Journal Name } & \multicolumn{3}{|c|}{ Research Method } \\
\cline { 2 - 4 } & $\begin{array}{c}\text { Analitycal } \\
\text { (percentage) }\end{array}$ & $\begin{array}{c}\text { Review } \\
\text { (percentage) }\end{array}$ & $\begin{array}{c}\text { Survey } \\
\text { (percentage) }\end{array}$ \\
\hline JAAI & $6(5,6 \%)$ & $4(7,1 \%)$ & $2(9,5 \%)$ \\
\hline JAKI & $3(2,8 \%)$ & $4(7,1 \%)$ & - \\
\hline AL-IQTISHAD & $46(43 \%)$ & $15(26,8 \%)$ & $8(38,1 \%)$ \\
\hline JAMAL & - & $7(12,5 \%)$ & - \\
\hline JKP & $26(24,3 \%)$ & $15(26,8 \%)$ & $5(23,8 \%)$ \\
\hline JEPI & $4(3,7 \%)$ & - & - \\
\hline Ventura & $7(6,6 \%)$ & $1(1,8 \%)$ & $5(23,8 \%)$ \\
\hline IQTISHADIA & $8(7,4 \%)$ & $9(16,1 \%)$ & $1(4,8 \%)$ \\
\hline Signifikan & $7(6,6 \%)$ & $1(1,8 \%)$ & 21 \\
\hline Total & 107 & 56 & - \\
\hline
\end{tabular}

\section{Conclusion}

In this study, we have analyzed 184 articles on Islamic economics which have been published in nine accredited journals in Indonesia from 2004 to 2017. Mostly the research articles on Islamic economics in Indonesia have generally been published in Al-Iqtishad. Meanwhile the common topics explored in the nine journals is the issue related to banking $(52,7 \%)$, with 97 articles. In addition, the most topics on disclosure of banking reaches at 46 articles. Topics on insurance is still limited, only six 
articles along with the topic of disclosure of 3 articles, product of 2 articles and system/regulation of 1 article.

The research method of the selected articles are by applying analytical methods of $58,2 \%$ (107 articles), literature review of $30,4 \%$ (56 articles) and survey of $11,4 \%$ (21 articles). The vast scope of Islamic economics invokes less detailed discussion. It is expected to deepen its discussion scope, for instance, in the field of insurance which has widely opened more debate. The further research may put their topics on insurance, or zakat, infaq or sadaqa since those are still rarely discussed in Indonesia. In addition, for the near future research, it is also expected to use more survey methods in the analysis of Islamic economic challenges. 


\section{References}

Abusharbeh, M.T. (2011). An Analysis of The Islamic and Conventional Banking Profitability in Palestine. Jurnal Akutansi Paradigma Vol 2(3). $381-390$.

Adawiyah, W. R. (2015). Dampak Penetrasi Bank Asing Terhadap Kinerja Keuangan Bank Islam di Indonesia. Jurnal Keuangan dan Perbankan Vol 19(1). 160-170.

Adawiyah, W. R. (2015). The Impact Of Financial Liberalization On Islamic Bank's Efficiency In Indonesia. Al-Iqtishad Vol VII(2).

Adiono, C.L. \& Sholihin, M. (2014). Analisis Pengungkapan Tata Kelola Bank Syariah di Indonesia. Jurnal Keuangan \& Perbankan Vol 18(2). $268-277$.

Adnan, M.A. \& Furywardhana, F. (2006). Evaluasi Non Performing Loan (NPL) Pinjaman Qardhul Hasan (Studi Kasus di BNI Syariah Cabang Yogyakarta). Jurnal Akutansi \& Auditing Indonesia Vol 10(2). $155-171$.

Affandi, A. \& Tamanni, L. (2010). Monetary Policy Shocks And Islamic Banks Deposits In Indonesian Dual Banking System After The Financial Crisis. Jurnal Keuangan dan Perbankan Vol 14(3). 491-500.

Agza, Y. \& Darwanto. (2017). Pengaruh Pembiayaan Murabahah, Musyarakah, dan Biaya Transaksi Terhadap Profitabilitas Bank Pembiayaan Rakyat Syariah. Iqtishadia Vol 10(1).

Aisyah, M. (2015). Peer Group Effects On Moslem Consumer's Decision To Purchase Halal-Labeled Cosmetics. Al-Iqtishad Vol VII(2).

Aisyah, M. (2017). Consumers Demand On Halal Cosmetics and Personal Care Products In Indonesian. Al-Iqtishad Vol 9(1). 125-142.

Aji, R. H. S. \& Kurniasih. (2015). The Intellectual Capital Effect On Financial Performances At Islamic Insurance. Al-Iqtishad Vol VII(2). 
Al Arif, M.N.R. (2015). Keterkaitan Kebijakan Pemisahan Terhadap Tingkat Efisiensi Pada Industri Perbankan Syariah di Indonesia. Jurnal Keuangan \& Perbankan Vol 19(2). 295-304.

Al Arif, M.N.R. \& Haribowo, I. (2016). Tipe Pemisahan dan Pengaruhnya Terhadap Laba Pada Bank Umum Syariah Hasil Pemisahan. Jurnal Keuangan \& Perbankan Vol 20(3). 479-486.

Al-Farisi, A. S. \& Hendrawan, R. (2010). Measuring Efficiency As Intermediation Approach Between Conventional And Sharia Banks In Indonesia. Jurnal Keuangan dan Perbankan Vol 14(3). 501-508.

Al Haq, M. A., Wahab, N. A \& Ahmad N, H. (2016). Islamic Prayer, Spirituality, and Productivity. An Exploratory Conceptual Analysis. Al-Iqtishad Vol V8(2). 271-286.

Ali, I.M.A. (2012). Memaknai Disclosure Laporan Sumber dan Penggunaan Dana Kebajikan (Qardhul Hasan) Bank Syariah. Jurnal Akutansi Paradigma Vol 3(2). 185-207.

Amalia, E. (2010). Perbankan Syariah Di Indonesia dan Peran Perguruan Tinggi Dalam Rangka Akselerasi. Jurnal Keuangan dan Perbankan Vol 14(1). 131-142.

Amelia, E. (2015). Financial Ratio and Its Influence To Profitability In Islamic Banks. Al-Iqtishad Vol VII(2).

Amalia, E. \& Atiqah, M. (2015). Evaluating The Models Of Sharia Microfinance In Indonesia: An Analytical Network Process (ANP) Approach. Al-Iqtishad Vol VII(1).

Amalia, F. (2014). Etika Bisnis Islam: Konsep dan Implementasi Pada Pelaku Usaha Kecil. Al-Iqtishad Vol 6(2).

Amalia, F. \& Nasution, M. E. (2007). Perbandingan Profitabilitas Industri Perbankan Syariah dan Industri Perbankan Konvensional Menggunakan Metode Struktur Kinerja dan Perilaku. Jurnal Ekonomi dan Pembangunan Indonesia Vol 7(2). 159-179. 
Amaliah, I. \& Aspiranti, T. (2017). State Sukuk Potential in Reducing Indonesia Budget Deficit 2009 - 2015. Journal of Economics, Business \& Accountancy Ventura Vol 20(1). 21-30.

Amilin. (2016). Fakta Empirik Tentang Etos Kerja Islam, Stres Kerja, Kepuasan Kerja, dan Kinerja Akuntan pada Industri Keuangan Islam di Indonesia. Iqtishadia Vol 9(2). 304-325.

Amin, M. (2017). Fatwa and The Development Of Sharia Financial Industry: A Lesson From Indonesia. Al-Iqtishad Vol 9(2). 331-350.

Andriati, R. \& Huda, N. (2015). The Influences Of Productive Zakah Mentoring To The Saving Behavior and The Prosperity Of Poor Housewife. Al-Iqtishad Vol VII(2).

Antonio, M.S. \& Nugraha, H.F. (2012). Peran Intermediasi Sosial Perbankan Syariah: Inisiasi Pelayanan Keuangan Bagi Masyarakat Miskin. Jurnal Keuangan \& Perbankan Vol 16(2). 238-252.

Ardiansyarh, M. K. I., Yunizar. \& Harsanto, B. (2016). Shari'ah-Compliant E-Commerce Models and Consumer Trust. Al-Iqtishad Vol V8(2). 243-254.

Arifin, J. \& Wardani, E.A. (2016). Islamic Corporate Social Responsibility Disclosure, Reputasi, dan Kinerja Keuangan: Studi pada Bank Syariah di Indonesia. Jurnal Akutansi \& Auditing Indonesia Vol 20(1).

Arif, M.N. \& Dewanti, E.P (2017). Metode Spin-Off dan Tingkat Profitabilitas: Studi Pada Bank Umum Syariah Hasil Spin-Off. Iqtishadia Vol 10(1). 23-43

Arifin, Z. (2014). Daya Tarik Pasar Modal Islami: Studi di Bursa Efek Indonesia. Jurnal Keuangan dan Perbankan Vol 18(2). 249-257.

Asnawi, N. \& Musowir, A. (2010). Relationship Marketing dan Loyalitas Nasabah : Studi Pada Nasabah BRI Syariah Malang. Jurnal Keuangan dan Perbankan Vol 14(2).319-328.

Asnawi, N., Siswanto \& Munir, M. (2011). Praktek Quran-Based Human Resource Management di Perbankan Syariah Berdasarkan 
Karakteristik Biografis. Jurnal Keuangan dan Perbankan Vol 15(1). 303-313.

Baehaqie, S., Fahmi, I. \& Beik, I. S. (2017). Determining Factors Of Deposit Level Of Islamic Bank In Indonesia. Al-Iqtishad Vol 9(2). 213-226.

Beik, I. S. \& Arsyianti, L. D. (2015). Construction Of Cibest Model As Measurement Of Poverty and Welfare Indices From Islamic Perspective. Al-Iqtishad Vol VII(1).

Beik, I. S. \& Fatmawati, S. W. (2014). Pengaruh Indeks Harga Saham Syariah Internasional dan Variabel Makro Ekonomi Terhadap Jakarta Islamic Index. Al-Iqtishad Vol 6(2).

Budiman, T., Kristanti, F. T. \& Wardhana. (2017). Islamic Bank Listed In Financial Market. Risk, Governance, Earning, and Capital. AlIqtishad Vol 9(1). 1-12.

Choliq, H.A. \& Misbach, I. (2016). Perbandingan Kualitas Layanan Bank Syariah dan Bank Konvensional (Pendekatan Model PBZ). Jurnal Keuangan \& Perbankan Vol 20(1). 127-140.

Dahlan, R. (2014). Faktor-Faktor Yang Mempengaruhi Persepsi Nazhir Terhadap Wakaf Uang. Al-Iqtishad Vol 6(2).

Dewi, S.S. \& Bawono, I.R. (2008). Analisis Pengaruh Etika Kerja Islam Terhadap Sikap Karyawan Bagian Akuntansi dalam Perubahan Organisasi (Studi Kasus pada Bank Umum Non Syariah di Wilayah Eks Karesidenan Banyumas Jawa Tengah). Jurnal Akutansi \& Auditing Indonesia Vol 12(1). 65-78.

Effendi, J., Baga, L. M. \& Beik, I. S. (2017). Aplikasi Model Bisnis Microfinance Syariah Terhadap Sektor UMKM di Indonesia. Iqtishadia Vol 10(2).

Effendi, J. \& Utami, A. R. (2016). The Effect Of Social Capital On Customer's Repayment Rate At Islamic Microfinance Institution. AlIqtishad Vol V8(2). 227-242. 
Effendi, K. A. (2017). Risk Of Debt-Based Financing In Indonesian Islamic Banking. Al-Iqtishad Vol 9(2). 203-212.

Ekasari, K. (2014). Hermeneutika Laba Dalam Perspektif Islam. Jurnal Akutansi Paradigma Vol 5(1). 67-75.

Endri. (2009). Permasalahan Pengembangan Sukuk Korporasi di Indonesia Menggunakan Metode Analytical Network Process (ANP). Jurnal Keuangan \& Perbankan Vol 13(3). 359-372.

Endri. (2010). Pengukuran Kinerja Efisiensi Perbankan Syariah : Analisis Empiris 15 Bank Syariah di Indonesia 2005-2007. Jurnal Ekonomi dan Pembangunan Indonesia Vol 10(2). 175-191.

Endri. (2011). Corporate Governance Terhadap Peringkat Sukuk Korporasi di Indonesia. Jurnal Keuangan \& Perbankan Vol 15(2). 178-190.

Ernawati. (2016). Risk Of Profit Loss Sharing Financing. The Case Of Indonesia. Al-Iqtishad Vol 8(1). 101-116.

Falikhatun., AssegaffY. U. \& Hasim. (2016). Menelisik Makna Pembiayaan Qardhul Hasan Dan Implementasinya Pada Perbankan Syariah di Indonesia. Jurnal Keuangan dan Perbankan Vol 20(1). 94-103.

Farhan, A. (2016). Hermeneutika Romantik Schleiermacher Mengenai Laba Dalam Muqaddimah Ibnu Khaldun. Jurnal Akutansi Paradigma Vol 7(1). 61-69.

Farhah, R. (2014). Efektivitas Layanan Weekend Banking (Studi Bank Muamalat KCP Pondok Indah Mall) . Al-Iqtishad Vol 6(2).

Fatimah, S. (2014). Pengaruh Rentabilitas, Efisiensi dan Likuiditas Terhadap Kecukupan Modal Bank Umum Syariah. Al-Iqtishad Vol 6(2).

Firmansyah, I. (2016). Determinan Return Saham Syariah Dengan Risiko Sistematis Sebagai Variabel Mediasi. Jurnal Keuangan \& Perbankan Vol 20(3) 358-368.

Hakim, L. (2016). Budaya Organisasi Islami Sebagai Upaya Meningkatkan Kinerja. Jurnal Iqtishadia Vol 9(1). 179-200. 
Hamid, A. (2015). The Impact Of Spin-Off Policy To The Profitability On Indonesian Islamic Banking Industry. Al-Iqtishad Vol VII(2).

Hamidi, M. (2017). Studi Komparasi Kinerja Bank Perkreditan Rakyat (BPR) Syariah dan Konvensional di Sumatera Barat. Iqtishadia Vol 10(1). 44-70.

Handriana, T. (2016). Analysis of Donor's Trust and Relationship Commitment in Lembaga Amil Zakat In Indonesia. Journal of Economics, Business \& Accountancy Ventura Vol 19(1). 59-68.

Harahap, H. (2014). Analisis Stabilitas Dinar Emas dan Dolar AS Dalam Denominasi Rupiah. Al-Iqtishad Vol 6(2).

Harahap, Darwis. (2017). Determinan Dana Pihak Ketiga Bank Syariah di Indonesia: Model Vector Autoregresive. Iqtishadia Vol 10(1).

Haribowo, I . (2017). The Indonesian Islamic Bank's Spin-Off. A Study In Regional Development Banks. Al-Iqtishad Vol 9(1). 53-68.

Hasbi, H. (2010). Kinerja Reksadana Syariah Tahun 2009 di Indonesia. Jurnal Keuangan \& Perbankan Vol 14(1). 62-73.

Hasbi, H. \& Suryawardani, B. (2013). Sistem Peringatan Dini Sebagai Pendukung Kinerja Perusahaan Asuransi Syariah. Jurnal Keuangan \& Perbankan Vol 17(2). 243-252.

Herianingrum, S. \& Syapriatama, I. (2016). Dual Monetary System and Macroeconomic Performance In Indonesia. Al-Iqtishad Vol 8(1). 6580.

Hesford, J. W., Lee, S. H., Van der Stede, W. A. \& Young, S. M. (2007). Management Accounting: A Bibliographic Study. Handbook of Management Accounting Research. Elsevier Ltd. All 16-39.

Hosen, M. N. \& Muhari, S. (2017). Liquidity and Capital Of Islamic Banks in Indonesia. Signifikan Vol 6(1). 49 - 68.

Huda, N,. Anggraini, D,. Mardoni, K. H. A Y. \& Rini, N. (2014). Prioritas Solusi Permasalahan Pengelolaan Zakat Dengan Metode AHP (Studi Di Banten dan Kalimantan Selatan). Al-Iqtishad Vol 6(2). 
Huda, N., Nazwirman. \& Hudori, K. (2017). Analisis Perbandingan Kinerja Reksa Dana Saham Syariah dan Konvensional Periode 20122015. Iqtishadia Vol 10(2).

Husein, M. F. \& Hasanah, S. M. (2016). Determining The Optimum Portfolio of Shariah Stocks Using an Approach of Shariah Compliant Asset Pricing Model (SCAPM). Journal of Economics, Business \& Accountancy Ventura Vol 19(3). 349-362.

Hidayat, R., Akhmad, S, Machmud (2015). Effects Of Service Quality, Customer Trust and Customer Religious Commitment On Customer Satisfaction and Loyalty Of Islamic Banks In East Java. Al-Iqtishad $\operatorname{Vol} \operatorname{VII}(2)$.

Hilmiyah, N., Possumah, B. T. \& Shafiai, H. M. (2017). Tawhidic Based Economic System. A Preliminary Conception. Al-Iqtishad Vol 9(1). 107-124.

Hosen, M. N. \& Rahmawati, R. (2016). Efficiency and Profitability On Indonesian Islamic Banking Industry. Al-Iqtishad Vol 8(1). 33- 48.

Huda, N., Rini, N., Anggraini, D., Hudori, K. \& Mardoni, Y. (2016). The Development Of Human Resources In Islamic Financial Industries From Economic and Islamic Financial Graduates. Al-Iqtishad Vol 8(1). 117-136.

Ibrahim, A. \& Rahmati, A. (2017). Analisis Solutif Penyelesaian Pembiayaan Bermasalah di Bank Syariah: Kajian Pada Produk Murabahah di Bank Muamalat Indonesia Banda Aceh. Iqtishadia Vol 10. 71-96.

Ichsan, N. (2014). Pengelolaan Likuiditas Bank Syariah. Al-Iqtishad Vol $6(2)$.

Isgiyarta, J. (2009). Perumusan Konsep Entitas Akuntansi Islam. Jurnal Akutansi \& Auditing Indonesia Vol 13(1). 77-86.

Iswandi, A. (2014). Peran Etika Qur'ani Terhadap Sistem Ekonomi Islam. Al-Iqtishad Vol 6(2). 
Iswanto, B. (2016). Peran Bank Indonesia, Dewan Syariah Nasional, Badan Wakaf Indonesia dan Baznas dalam Pengembangan Produk Hukum Ekonomi Islam di Indonesia. Iqtishadia Vol 9(2). 421-439.

Kasdi, A. (2016). Filantropi Islam Untuk Pemberdayaan Ekonomi Umat (Model Pemberdayaan ZISWAF di BMT Se-Kabupaten Demak). Iqtishadia Vol 9(2). 227-245.

Kasri, R. A. \& Iman, N. (2010). Analisis Persaingan Bank Syariah Indonesia : Aplikasi Model Panzar-Rosse. Jurnal Ekonomi dan Pembangunan Indonesia Vol 11(1). 1-20.

Kasri, R. A. (2016). Effectiveness Of Zakah Targeting In Alleviating Poverty In Indonesia Al-Iqtishad Vol V8(2). 169-186.

Khajar, I. (2012). Efisiensi Pasar Modal Syariah Indonesia Sebelum dan Sesudah Krisis Finansial Global 2008. Jurnal Keuangan dan Perbankan Vol 16(1). 66-76.

Khairunisa, R., Akbar, N. \& Devi, A. (2017). Exploring Strategies To Enhance Islamic Banking's Role To Raise Cash Waqf Funds. Iqtishadia Vol 10(2).

Khan, T. N. (2016). Islamic Banks Service Innovation Quality. Conceptual Model. Al-Iqtishad Vol V8(2). 287-306.

Kholid, M.N. \& Bachtiar, A. (2015). Good Corporate Governance Dan Kinerja Maqasid Syariah Bank Syariah di Indonesia. Jurnal Akutansi \& Auditing Indonesia Vol 19(2). 126-136.

Kusmayadi, D., Firmansyah, I. \& Badruzaman, J. (2017). The Impact Of Macroeconomic On Nonperforming Loan: Comparison Study at Conventional and Islamic Banking. Iqtishadia Vol 10(2).

Laela, S.F. (2007). Dynamic Strategic-Fit Dan Kinerja: Studi Pada Perbankan Syariah. Jurnal Akutansi \& Keuangan Indonesia Vol 11(1). 20-39.

Laela, S.F. (2016). Kualitas Laba Dan Corporate Governance: Benarkah Kualitas Laba Bank Syariah Lebih Rendah Dari Bank Konvensional?. 
Jurnal Akutansi \& Keuangan Indonesia Vol 13(2). 160-173.

Maharani, S.N. (2008). Menyibak Agency Problem Pada Kontrak Mudharabah dan Alternatif Solusi. Jurnal Keuangan \& Perbankan Vol 12(3). 479-493.

Majid, J. \& Haliding, S. (2014). The Critical Aspect On Fair Value Accounting and Its Implication To Islamic Financial Institutions. AlIqtishad Vol 6(2).

Majid, J. \& Haliding, S. (2014). The Need for the Islamization of Knowledge in Accounting. Al-Iqtishad Vol 6(2).

Majid, M. S. A. (2017). The Motivation Of Muzakki To Pay Zakah: Study At The Baitul Mal Aceh. Signifikan Vol 6(1). 159 - 176.

Majid, M. S. A. (2017). The Motivation Of Muzakki To Pay Zakah: Study At The Baitul Mal Aceh. Signifikan Vol 6(1). 159 - 176.

Majid, M. S. A. (2016). The Short-Run and Long-Run Relationship In Indonesian Islamic Stock Returns. Al-Iqtishad Vol 8(1). 1-18.

Majid, M. S. A. \& Zulhanizar, S. (2016). The Patronage Behaviour Of Islamic Bank's Customers. Empirical Studies In Aceh. Al-Iqtishad Vol V8(2). 201-212.

Manzilati, A. (2010). Kesepakatan Kelembagaan Kontrak Mudharabah Dalam Kerangka Teori Keagenan. Jurnal Keuangan dan Perbankan Vol 15(2). 281-293.

Mariyono, J. (2012). Determinants of Customers in Selecting Sharia Banking System For Saving in East Java - Indonesia . Journal of Economics, Business \& Accountancy Ventura Vol 16(3). 457-472.

Marsuki. (2010). Problem and Perspective of Islamic Monetary Policy in Indonesia. Jurnal Keuangan \& Perbankan Vol 14(3). 435-446.

Meutia, I. (2010). The Concept Of Social Responsibility Disclosures For Islamic Banks Based on Shari'ah Enterprise Theory. Jurnal Akutansi Paradigma Vol 1(3). 
Miftah, K. \& Wibowo, H. (2017). Merger and Industrial Acceleration: Study at Indonesian Islamic Banking Industry. Signifikan Vol 6(1). $29-48$.

Muhammad, R. (2009). Studi Evaluatif Terhadap Laporan Perbankan Syariah. Jurnal Akutansi \& Auditing Indonesia Vol 13(2). 189-209.

Muhammad, R. (2010). Persepsi User Dan Preparer Laporan Keuangan Terhadap Pelaporan Sosial Perbankan Islam di Malaysia. Jurnal Akutansi \& Auditing Indonesia Vol 14(2).

Mukhlis, I. (2012). Kinerja Keuangan Bank Dan Stabilitas Makroekonomi Terhadap Profitabilitas Bank Syariah di Indonesia. Jurnal Keuangan \& Perbankan Vol 16(2). 275-285.

Mulawarman, A.D. (2007). Menggagas Neraca Syari'ah Berbasis Maal: Kontekstualisasi "Kekayaan Altruistik Islami”. Jurnal Akutansi \& Keuangan Indonesia Vol 4(2). 169-192.

Mulawarman, A.D., Triyuwono, I. \& Ludigdo, U. (2012). Rekonstruksi Teknologi Integralistik Akuntansi Syari'ah: Shariate Value Added Statement. Jurnal Akutansi \& Keuangan Indonesia Vol 4(1). 1-24.

Nasution, M. E. \& Wiliasih, R. (2007). Profit Sharing dan Moral Hazard Dalam Penyaluran Dana Pihak Ketiga Bank Umum Syariah di Indonesia. Jurnal Ekonomi dan Pembangunan Indonesia Vol 8(2). 231 255.

Ningsih, E. R. (2016). Pengaruh Kualitas Pelayanan B2B Perbankan Syari'ah dan Cultural Fit Pada Kepuasan, Loyalitas, dan Rekomendasi positif. Iqtishadia Vol 9(1). 53-80.

Ningsih, E. R. (2017). Studi Eksplorasi Penerapan Etika Bisnis Pada Perbankan Syari'Ah di Indonesia. Iqtishadia Vol 10. 1-22.

Nugraheni, P. (2011). Voluntary Disclosure in Indonesia: Comparison of Shariah And Non-Shariah Compliant Companies. Jurnal Akutansi \& Auditing Indonesia Vol 15(1). 53-64. 
Nugraheni, P. \& Wijayanti, R. (2017). Analysis of Factors Affecting The Disclosure of Islamic Social Reporting (an empirical study on the Sharia Securities List). Journal of Economics, Business \& Accountancy Ventura Vol 20(1). 103-112.

Nuryartono, N., Saptono, I. T. \& Was'an, G. H. (2016). Kaitan Kondisi Makroekonomi Dengan Non Performing Financing Berdasarkan Sektor Ekonomi Pada Perbankan Syariah di Indonesia. Jurnal Keuangan dan Perbankan Vol 20(1). 104-115.

Oktaviani, M. (2015). Early Warning System dan Pertumbuhan Pendapatan Kontribusi Pada Perusahaan Asuransi Jiwa Syariah di Indonesia. Jurnal Keuangan \& Perbankan Vol 19(2). 271-282.

Prabowo, H.Y. (2004). Describing The Undescribed (The Odd Revenue Sharing of PSAK No. 59). Jurnal Akutansi \& Auditing Indonesia Vol $8(2)$.

Prasetyia, F. \& Diendtara, K. (2010). Pengukuran Efisiensi Perbankan Syariah Berbasis Manajemen Risiko. Jurnal Keuangan \& Perbankan Vol 15(1). 119-129.

Prasetyo, W. (2011). Pembiayaan Prinsip Bagi Hasil, Prinsip Jual Beli dan Prinsip Sewa Terhadap Falah Laba. Jurnal Keuangan \& Perbankan Vol 15(3). 456-465.

Prasetyo, A. \& Pratiwi, I. K. (2016). Islamic Business Ethics Implementation In Marketing Communication Of Hajj/Umroh Travel Agency "X" Surabaya. Al-Iqtishad Vol 8(1). 81-100.

Pratama, Y. C. (2015). Macroeconomic Variable and Its Influence On Performance Of Indonesian Islamic Banking. Al-Iqtishad Vol VII(1).

Puspitasari, N. (2012). Model Proporsi Tabarru' dan Ujrah Pada Bisnis Asuransi Umum Syariah di Indonesia. Jurnal Akutansi \& Keuangan Indonesia Vol 9(1). 43-55.

Puspitasari, N. (2016). Determinan Proporsi Dana Tabarru’ Pada Lembaga Keuangan Asuransi Umum Syariah. Jurnal Akutansi \& Keuangan Indonesia Vol 13(2). 160-173. 
Putra, D. P. \& Indra. (2016). Determinant of The Poverty in The Moslem Countries: Ibn Khaldun Development Model. Signifikan Vol 5(1). $15-30$.

Qomariah, N., Sari, M.I. \& Budiarti, D.A. (2016). Perbandingan Kinerja Reksadana Syariah dan Reksadana Konvensional (Pada Reksadana Saham dan Reksadana Pendapatan Tetap yang Terdaftar di BEI Periode 2010-2014). Jurnal Keuangan \& Perbankan Vol 20(3). 417-427.

Qoyum, A., Mutma'inah, L. \& Setyono, J. (2017). The Impact of Good Corporate Governance, Company Size nn Corporate Social Responsibility Disclosure: Case Study of Islamic Banking in Indonesia. Iqtishadia Vol 10(1).

Rahmayati, A. (2016). Islamic Bond: An Alternative To Local Government Financing. Signifikan Vol 5(1). 83 - 98.

Rama, A. \& Makhlani. (2014). Analisis Kesesuaian Konstitusi Ekonomi Indonesia Terhadap Ekonomi Islam. Al-Iqtishad Vol 6(2).

Reni, A. \& Ahmad, N. H. (2016). Application Of Theory Reasoned Action In Intention To Use Islamic Banking In Indonesia. Al-Iqtishad Vol 8(1). 137-148.

Ridho, S.L.Z. (2013). Perbankan Syariah dan Pengangguran: Suatu Aplikasi Empiris Teori Search and Matching Model. Jurnal Keuangan \& Perbankan Vol 17(1). 156-157.

Rini. (2014). The Effect of Audit Committee Role and Sharia Supervisory Board Role on Financial Reporting Quality at Islamic Banks in Indonesia. Journal of Economics, Business \& Accountancy Ventura Vol 17(1). 145-156.

Rini. (2016). Penerapan Internet Financial Reporting Untuk Meningkatkan Akuntabilitas Organisasi Pengelola Zakat. Jurnal Akutansi Paradigma Vol 7(2). 288-306.

Risza, H. (2014). Kritik Ilmu Ekonomi Strukturalis dan Islam Terhadap Ekonomi Neoklasikal. Al-Iqtishad Vol 6(2). 
Rodoni, A. \& Setiawan, A. (2016). Risk and Return. Bonds and Sukuk In Indonesia. Al-Iqtishad Vol V8(2). 255-270.

Rodoni, A., Salim, M. A., Amalia, E. \& Rakhmadi, R. S. (2017). Comparing Efficiency and Productivity In Islamic Banking: Case Study In Indonesia, Malaysia and Pakistan. Al-Iqtishad Vol 9(2). $227-$ 242.

Rokhman, W. (2016). Pengaruh Biaya, Angsuran dan Kualitas Pelayanan Terhadap Kepuasan Nasabah Pembiayaan BMT di Kabupaten Kudus. Iqtishadia Vol 9(2). 326-351.

Ruhadi \& Mai, M. U. (2017). Bankruptcy Model Analysis. Comparative Studies Between Sharia and Non Sharia Manufacturing Companies. Al-Iqtishad Vol 9(2). 311-330.

Rusydiana, A. S. \& Al-Farisi, S. (2016). The Efficiency Of Zakah Institutions Using Data Envelopment Analysis. Al-Iqtishad Vol V8(2). 213-226.

Rusydiana, A. S. \& Devi, A. (2016). Islamic Group Lending and Financial Inclusion. Signifikan Vol 5(1). 51 - 68.

Ryandini, T. (2014). Pengaruh Dana Investasi Melalui Instrumen SUN dan SBSN Terhadap Pertumbuhan Ekonomi Indonesia. Al-Iqtishad Vol 6(2).

Sabiti, B. S. \& Effendi, J. (2017). Islamic Microfinance And Its Impact On Poverty Reduction In Bogor. Signifikan Vol 6(1). 87 - 102.

Sadhana, K. (2012). Sosialisasi dan Persepsi Bank Syariah (Kajian Kebijakan Enkulturasi Nilai-Nilai Bank Syariah dalam Masyarakat). Jurnal Keuangan \& Perbankan Vol 16(3). 481-488.

Saharuddin, D. \& Rama, A. (2017). Currency System and It's Impact On Economic Stability. Al-Iqtishad Vol 9(2). 289-310.

Salamudin. (2014). Pengaruh Biaya Promosi Terhadap Peningkatan Jumlah Peserta Asuransi: Studi Di AJB Bumiputera 1912 Divisi Syariah. Al-Iqtishad Vol 6(2). 
Sanrego, Y.D. \& Rusydiana, A.S. (2009). Peran Perbankan Syariah Dalam Mendorong Agro Investasi. Jurnal Keuangan \& Perbankan Vol 13(2). 311-324.

Sawarjuwono, T., Basuki, B. \& Harymawan, I. (2011). Menggali Nilai, Makna, dan Manfaat Perkembangan Sejarah Pemikiran Akuntansi Syariah di Indonesia. Jurnal Akutansi \& Auditing Indonesia Vol 15(1). $65-82$.

Setianingrum, A. (2015). Application Of Pattern Of Islamic State Revenue Policy To Improve The Ability Of Indonesia's Fiscal. Al-Iqtishad Vol $\operatorname{VII}(2)$.

Seto, S.H. (2005). Menggagas Pembiayaan Pembangunan Infrastruktur di Indonesia Melalui Obligasi Syariah. Jurnal Akutansi \& Keuangan Indonesia Vol 2(1). 58 - 76.

Setyawan, I. \& Atahau, A.D.R. (2010). Cost of Capital Pada Bank Syariah Mandiri Periode 2004-2008. Jurnal Keuangan \& Perbankan Vol 14(1). 143 - 166.

Setyawan, S. H. \& Laksito, H. (2008). Pengujian Pecking Order Theory Pada Emiten Syariah di Bursa Efek Jakarta. Jurnal Keuangan dan Perbankan Vol 12(1). 22-28.

Shobirin. (2016). Penyelesaian Pembiayaan Murabahah Bermasalah Di Baitul Maal Wa Tamwil ( BMT ). Iqtishadia Vol 9(2). 398-420.

Siswanti, I. (2016). Implementasi Good Corporate Governance Pada Kinerja Bank Syariah. Jurnal Akutansi Paradigma Vol 7(2). 307 - 321.

Sugema, I., Bakhtiar,T. \& Effendi, J. (2009). Keunggulan Sistem Keuangan Berbasis Bagi Hasil dan Implikasinya Pada Distribusi Pendapatan. Jurnal Keuangan dan Perbankan Vol 13(3). 506 - 517.

Sukmana, R. \& Suryaningtyas, S. (2016). Determinants Of Liquidity Risk In Indonesian Islamic and Conventional Banks. Al-Iqtishad Vol V8(2). 187-200. 
Sunarsih, U. \& Ferdiyansyah. (2017). Determinants Of The Islamic Social Reporting Disclosure. Al-Iqtishad Vol 9(1). 69-80.

Suryani. (2014). Analisis Faktor Kualitas Pelayanan Di Bank Syariah. AlIqtishad Vol 6(2).

Suryani \& Hendryadi. (2015). A Developing Model Of Relationship Among Service Quality, Consumer Satisfaction, Loyalty and Word Of Mouth In Islamic Banking Al-Iqtishad Vol VII(1).

Suryanto, T. (2016). Islamic Work Ethics and Audit Opinions. Audit

Professionalism and Dysfunctional Behavior As Intervening Variables. Al-Iqtishad Vol 8(1). 49-64.

Suparto. (2008). Perilaku Dan Kepuasan Pelanggan Bank Muamalat Indonesia Cabang Surabaya Dengan Menggunakan Analisis Regresi Logistik. Jurnal Keuangan \& Perbankan Vol 12(2). 331 - 341.

Suprianto, Edy. \& Setiawan, Doddy. (2017). Manajemen Laba di Indonesia: Studi Sebuah Bibliograpi. Jurnal Keuangan dan Perbankan. Vol 21(2). 287-301.

Susana, E. (2009). Analisis dan Evaluasi Mekanisme Pelaksanaan Pembiayaan Al-Musyarakah Pada Bank Syariah. Jurnal Keuangan dan Perbankan Vol 13(1). 176-184.

Susana, E. (2009). Karakteristik Individu dan Lingkungan Kerja Terhadap Prestasi Kerja Karyawan Bank Syariah. Jurnal Keuangan dan Perbankan Vol 13(3). 534-546.

Susana, E. \& Kartika, D. (2010). Pelaksanaan Pembiayaan Dana Talangan Haji Pada Perbankan Syariah. Jurnal Keuangan dan Perbankan Vol 7(2). 323-332.

Susana, E. \& Prasetyanti, A. (2011). Pelaksanaan dan Sistem Bagi Hasil Pembiayaan Al-Mudharabah Pada Bank Syariah. Jurnal Keuangan dan Perbankan Vol 15(3). 466-478.

Sutawi. (2008). Pembiayaan Syariah Pada Usaha Mikro, Kecil, dan Menengah Sektor Agribisnis dengan Pola Kemitraan. Jurnal Keuangan 
dan Perbankan Vol 12(3). 447-458.

Sutrisno. (2015). Perbankan Syariah: Antara Idealisme dan Oportunisme Studi Kasus Pada Perbankan Syariah di Indonesia Jurnal Keuangan \& Perbankan Vol 19(3). 418 - 430.

Sutrisno. (2017). Pengukuran Kesehatan Bank Syariah Dengan Sharia Complience and Performance. Jurnal Keuangan dan Perbankan Vol 21(1). 133-143.

Syafrida, I., Aminah, I. \& Waluyo, B. (2014). Perbandingan Kinerja Instrumen Investasi Berbasis Syariah Dengan Konvensional Pada Pasar Modal Di Indonesia. Al-Iqtishad Vol 6(2).

Tanjung, H. (2014). Volatility Of Jakarta Islamic Index. Al-Iqtishad Vol $6(2)$.

Terminanto, A. \& Rama, A. (2017). Pengaruh Belanja Pemerintah dan Pembiayaan Bank Syariah Terhadap Pertumbuhan Ekonomi : Studi Kasus Data Panel Provinsi di Indonesia. Iqtishadia Vol 10(1).

Tobing, D.S.K., Fathorazzi, M. \& Wulandari, G.A. (2016). Model Inovasi Sistem Pemasaran Perbankan Syariah Berbasis Floating Market Untuk Penciptaan Daya Saing (Model of Islamic Banking Marketing Innovation Systems Based on Floating Market For Creation Competitiveness). Jurnal Keuangan \& Perbankan Vol 20(1) 75 - 83.

Trisnawati, R. (2012). Pengukuran Tanggung Jawab Sosial Perusahaan Perbankan Syariah di Indonesia. Jurnal Akutansi \& Auditing Indonesia Vol 16(2). $103-121$.

Tulasmi. \& Trihariyanto, R. R. (2016). Islamic Stocks Index Performance: Comparative Studies Between Indonesia and Malaysia. Signifikan Vol 5(1). 69-82.

Usman, H. (2015). The Role Of Religious Norms On Selecting The Islamic Bank. Al-Iqtishad Vol VII(1).

Wahab, A., Hosen, M. N. \& Muhari, S. (2014). Komparasi Efisiensi Teknis Bank Umum Konvensional (BUK) dan Bank Umum Syariah 
(BUS) Di Indonesia Dengan Metode Data Envelopment Analysis (DEA). Al-Iqtishad Vol 6(2).

Wahyuni, S. (2015). Kepribadian Merek Dan Ikatan Emosional Merek Terhadap Loyalitas Merek Tabungan Bank Umum Syariah. Jurnal Keuangan \& Perbankan Vol 19(2). 336 - 346.

Wahyuni, S. \& Pujiharto. (2016). Profit Efficiency of Shariah Banks In Indonesia and The Determining Factors: Using Stochastic Frontier Analysis Method. Journal of Economics, Business \& Accountancy Ventura Vol 19(2). $271-282$.

Warninda, T. D. \& Hosen, M. N. (2015). Mapping and Correlation Analysis Of Efficiency and Profitability. The Case Of Islamic Rural Bank In Indonesia. Al-Iqtishad Vol VII(1).

Warsito, C. (2015). The Image Of Financial Institution As Islamic Bank In Mediation Service Quality and Customer Satisfaction On Customer Loyalty In Purwokerto. Al-Iqtishad Vol VII(2).

Wibowo, B. (2017). Pergerakan Bersama Indeks Pasar Saham Syariah dan Variabel Makro Ekonomi: Pendekatan Regime-Switching Regression. Iqtishadia Vol 10(2).

Widarwati, E., Afif, N. C. \& Zazim, M. (2017). Strategic Approach For Optimizing Of Zakah Institution Performance. Customer Relationship Management. Al-Iqtishad Vol 9(1). 81-94.

Widigdo, A. M. N., Marimin, Fahmi, I., Beik, I. S. (2016). Business Process Reengineering Of Funding On Indonesia’s Islamic Banks. AlIqtishad Vol 8(1). 19-32.

Wijaya, I. F. (2014). The Objective Of Islamic Bank: A Case Study in Surakarta Region. Jurnal Keuangan dan Perbankan Vol 18(3). 489496.

Wiranatakusuma, D. B. \& Duasa, J. (2017). Building An Early Warning Towards The Resilience Of Islamic Banking In Indonesia. Al-Iqtishad Vol 9(1). 13-32. 
Yuafi, H. \& Bawono, A. (2017). Islamic Banking Existence and Domestic Credit. Study At Seven Countries. Al-Iqtishad Vol 9(2). 185-202.

Yuliana, R. \& Alim, M. N. (2017). The Islamic Capital Market Response to The Real Earnings Management. Journal of Economics, Business \& Accountancy Ventura Vol 20(1). 61 - 69.

Yulianti, Suzanawaty, L., Putri, Z. E. \& Haribowo, I. (2016). Determinant Of The Corporate Environmental Disclosure. Study On Jakarta Islamic Index. Al-Iqtishad Vol V8(2). 307-322.

Yahya, M. (2012). Tingkat Suku Bunga Bank Konvensional dan Komitmen Nasabah Menabung di Bank Syariah. Jurnal Keuangan \& Perbankan Vol 16(2). $253-263$.

Yunan, Z. Y. \& Rahmasari, M. (2015). Measurement Of Shariah Stock Performance Using Risk Adjusted Performance. Al-Iqtishad Vol $\operatorname{VII}(1)$.

Yaya, R. (2004). Would The Objectives And Characteristics of Islamic Accounting For Islamic Business Organizations Meet The Islamic Socio-Economic Objectives?. Jurnal Akutansi \& Auditing Indonesia Vol 8(2).

Yusuf, B. (2015). Human Resources Development Of Sharia Banking. Phenomenological Approach. Al-Iqtishad Vol VII(2).

Yusuf, M.Y. \& Mahriana W. S. (2016). Faktor-Faktor yang Mempengaruhi Tingkat Profitabilitas Bank Pembiayaan Rakyat Syariah (BPRS) Di Aceh. Iqtishadia Vol 9(2). 246-275.

Yulita, I . \& Rizal, S. (2016). Islamic Banking Efficiency: Comparative Studies Between Malaysia and Indonesia. Signifikan Vol 5(1). 31 - 50.

Zubair, M. K. (2016). Analisis Faktor-Faktor Sustainabilitas Lembaga Keuangan Mikro Syariah. Iqtishadia Vol 9(2). 201-226.

Undang-undang Nomor 7 Tahun 1992

Undang-undang Nomor 10 Tahun 1998

Sindonews.https://ekbis.sindonews.com/read/1237105/35/indonesiaperingkat-ke-5-ekonomi-paling-kuat-di-dunia-1504673818 


\section{Appendix}

Appendix 1. List of Sample Articles

\begin{tabular}{|c|c|c|c|}
\hline No & Journal & Titles & Researchers \\
\hline 1 & JAAI & $\begin{array}{l}\text { Evaluasi Non Performing Loan (NPL) } \\
\text { Pinjaman Qardhul Hasan (Studi Kasus Di } \\
\text { BNI Syariah Cabang Yogyakarta) }\end{array}$ & $\begin{array}{c}\text { Adnan \& } \\
\text { Furywardhana (2006) }\end{array}$ \\
\hline 2 & JAAI & $\begin{array}{l}\text { Persepsi User Dan Preparer Laporan } \\
\text { Keuangan Terhadap Pelaporan Sosial } \\
\text { Perbankan Islam Di Malaysia }\end{array}$ & Muhammad (2010) \\
\hline 3 & JAAI & $\begin{array}{l}\text { Studi Evaluatif Terhadap Laporan } \\
\text { Perbankan Syariah }\end{array}$ & Muhammad (2009) \\
\hline 4 & JAAI & $\begin{array}{l}\text { Would The Objectives And Characteristics } \\
\text { Of Islamic Accounting For Islamic Business } \\
\text { Organizations Meet The Islamic Socio- } \\
\text { Economic Objectives? }\end{array}$ & Yaya (2004) \\
\hline 5 & JAAI & $\begin{array}{l}\text { Voluntary Disclosure In Indonesia: } \\
\text { Comparison Of Shariah And Non-Shariah } \\
\text { Compliant Companies }\end{array}$ & Nugraheni (2011) \\
\hline 6 & JAAI & $\begin{array}{l}\text { Pengukuran Tanggung Jawab Sosial } \\
\text { Perusahaan Perbankan Syariah Di Indonesia }\end{array}$ & Trisnawati (2012) \\
\hline 7 & JAAI & $\begin{array}{l}\text { Good Corporate Governance Dan Kinerja } \\
\text { Maqasid Syariah Bank Syariah Di Indonesia }\end{array}$ & $\begin{array}{l}\text { Kholid \& Bachtiar } \\
\text { (2015) }\end{array}$ \\
\hline 8 & JAAI & Perumusan Konsep Entitas Akuntansi Islam & Isgiyarta (2009) \\
\hline 9 & JAAI & $\begin{array}{l}\text { Islamic Corporate Social Responsibility } \\
\text { Disclosure, Reputasi, Dan Kinerja } \\
\text { Keuangan: Studi Pada Bank Syariah Di } \\
\text { Indonesia } \\
\end{array}$ & $\begin{array}{l}\text { Arifin \& Wardani } \\
\qquad(2016)\end{array}$ \\
\hline 10 & JAAI & $\begin{array}{l}\text { Analisis Pengaruh Etika Kerja Islam } \\
\text { Terhadap Sikap Karyawan Bagian Akuntansi } \\
\text { Dalam Perubahan Organisasi (Studi Kasus } \\
\text { Pada Bank Umum Non Syariah Di Wilayah } \\
\text { Eks Karesidenan Banyumas Jawa Tengah) } \\
\end{array}$ & $\begin{array}{l}\text { Dewi \& Bawono } \\
\quad(2008)\end{array}$ \\
\hline 11 & JAAI & $\begin{array}{l}\text { Describing The Undescribed (The Odd } \\
\text { Revenue Sharing Of PSAK No. 59) }\end{array}$ & Prabowo (2004) \\
\hline 12 & JAAI & $\begin{array}{l}\text { Menggali Nilai, Makna, Dan Manfaat } \\
\text { Perkembangan Sejarah Pemikiran Akuntansi } \\
\text { Syariah Di Indonesia }\end{array}$ & $\begin{array}{l}\text { Sawarjuwono Et } A l \\
\text { (2011) }\end{array}$ \\
\hline 13 & JAKI & $\begin{array}{l}\text { Model Proporsi Tabarru’ Dan Ujrah } \\
\text { Pada Bisnis Asuransi Umum Syariah Di } \\
\text { Indonesia }\end{array}$ & Puspitasari (2012) \\
\hline
\end{tabular}




\begin{tabular}{|c|c|c|c|}
\hline 14 & JAKI & $\begin{array}{l}\text { Menggagas Pembiayaan Pembangunan } \\
\text { Infrastruktur Di Indonesia Melalui Obligasi } \\
\text { Syariah }\end{array}$ & Seto $(2005)$ \\
\hline 15 & JAKI & $\begin{array}{l}\text { Determinan Proporsi Dana Tabarru’ Pada } \\
\text { Lembaga Keuangan Asuransi Umum } \\
\text { Syariah }\end{array}$ & Puspitasari (2016) \\
\hline 16 & JAKI & \begin{tabular}{|l|} 
Kualitas Laba Dan Corporate Governance: \\
Benarkah Kualitas Laba Bank Syariah Lebih \\
Rendah Dari Bank Konvensional? \\
\end{tabular} & Laela (2012) \\
\hline 17 & JAKI & $\begin{array}{l}\text { Rekonstruksi Teknologi Integralistik } \\
\text { Akuntansi Syari'ah: Shariate Value Added } \\
\text { Statement }\end{array}$ & $\begin{array}{c}\text { Mulawarman Et } A l \\
\quad(2007)\end{array}$ \\
\hline 18 & JAKI & $\begin{array}{l}\text { Menggagas Neraca Syariah Berbasis Maal: } \\
\text { Kontekstualisasi “Kekayaan Altruistik } \\
\text { Islami” }\end{array}$ & Mulawarman (2007) \\
\hline 19 & JAKI & $\begin{array}{l}\text { Dynamic Strategic-Fit Dan Kinerja: Studi } \\
\text { Pada Perbankan Syariah }\end{array}$ & Laela (2014) \\
\hline 20 & JAMAL & $\begin{array}{l}\text { The Concept Of Social Responsibility } \\
\text { Disclosures For Islamic Banks Based On } \\
\text { Shari'ah Enterprise Theory }\end{array}$ & Meutia (2010) \\
\hline 21 & JAMAL & $\begin{array}{l}\text { An Analysis Of The Islamic And } \\
\text { Conventional Banking Profitability In } \\
\text { Palestine }\end{array}$ & Abusharheh (2011) \\
\hline 22 & JAMAL & $\begin{array}{l}\text { Memaknai Disclosure Laporan Sumber } \\
\text { Dan Penggunaan Dana Kebajikan (Qardhul } \\
\text { Hasan) Bank Syariah }\end{array}$ & Ali (2012) \\
\hline 23 & JAMAL & Hermeneutika Laba Dalam Perspektif Islam & Ekasari (2014) \\
\hline 24 & JAMAL & $\begin{array}{l}\text { Hermeneutika Romantik Schleiermacher } \\
\text { Mengenai Laba Dalam Muqaddimah Ibnu } \\
\text { Khaldun }\end{array}$ & Farhan (2016) \\
\hline 25 & JAMAL & $\begin{array}{l}\text { Penerapan Internet Financial Reporting } \\
\text { Untuk Meningkatkan Akuntabilitas } \\
\text { Organisasi Pengelola Zakat }\end{array}$ & Rini (2016) \\
\hline 26 & JAMAL & $\begin{array}{l}\text { Implementasi Good Corporate Governance } \\
\text { Pada Kinerja Bank Syariah }\end{array}$ & Siswanti (2016) \\
\hline 27 & JKP & $\begin{array}{l}\text { Perbankan Syariah: Antara Idealisme Dan } \\
\text { Oportunisme Studi Kasus Pada Perbankan } \\
\text { Syariah Di Indonesia }\end{array}$ & Sutrisno $(2015)$ \\
\hline 28 & JKP & $\begin{array}{l}\text { Tipe Pemisahan Dan Pengaruhnya Terhadap } \\
\text { Laba Pada Bank Umum Syariah Hasil } \\
\text { Pemisahan }\end{array}$ & $\begin{array}{l}\text { Al Arif \& Haribowo } \\
\text { (2016) }\end{array}$ \\
\hline
\end{tabular}




\begin{tabular}{|c|c|c|c|}
\hline 29 & JKP & $\begin{array}{l}\text { Perbandingan Kinerja Reksadana Syariah } \\
\text { Dan Reksadana Konvensional (Pada } \\
\text { Reksadana Saham Dan Reksadana } \\
\text { Pendapatan Tetap Yang Terdaftar Di BEI } \\
\text { Periode 2010-2014) }\end{array}$ & $\begin{array}{l}\text { Qomariah Et } A l \\
\quad(2016)\end{array}$ \\
\hline 30 & JKP & $\begin{array}{l}\text { Perbankan Syariah Dan Pengangguran: } \\
\text { Suatu Aplikasi Empiris Teori Search And } \\
\text { Matching Model }\end{array}$ & Ridho (2013) \\
\hline 31 & $\mathrm{JKP}$ & $\begin{array}{l}\text { Analisis Pengungkapan Tata Kelola Bank } \\
\text { Syariah Di Indonesia }\end{array}$ & $\begin{array}{l}\text { Adiono \& Sholihin } \\
\text { (2014) }\end{array}$ \\
\hline 32 & JKP & $\begin{array}{l}\text { Keterkaitan Kebijakan Pemisahan Terhadap } \\
\text { Tingkat Efisiensi Pada Industri Perbankan } \\
\text { Syariah Di Indonesia }\end{array}$ & Al Arif (2015) \\
\hline 33 & JKP & $\begin{array}{l}\text { Perilaku Dan Kepuasan Pelanggan Bank } \\
\text { Muamalat Indonesia Cabang Surabaya } \\
\text { Dengan Menggunakan Analisis Regresi } \\
\text { Logistik }\end{array}$ & Suparto (2008) \\
\hline 34 & $\mathrm{JKP}$ & $\begin{array}{l}\text { Peran Perbankan Syariah Dalam } \\
\text { Mendorong Agro Investasi }\end{array}$ & $\begin{array}{c}\text { Sanrego \& Rusydiana } \\
\text { (2009) }\end{array}$ \\
\hline 35 & JKP & $\begin{array}{l}\text { Kinerja Reksadana Syariah Tahun } 2009 \text { Di } \\
\text { Indonesia }\end{array}$ & Hasbi (2010) \\
\hline 36 & JKP & $\begin{array}{l}\text { Problem And Perspective Of Islamic } \\
\text { Monetary Policy In Indonesia }\end{array}$ & Marsuki (2010) \\
\hline 37 & JKP & $\begin{array}{l}\text { Pengukuran Efisiensi Perbankan Syariah } \\
\text { Berbasis Manajemen Risiko }\end{array}$ & $\begin{array}{c}\text { Prasetya \& Diendtara } \\
(2011)\end{array}$ \\
\hline 38 & $\mathrm{JKP}$ & $\begin{array}{l}\text { Corporate Governance Terhadap Peringkat } \\
\text { Sukuk Korporasi Di Indonesia }\end{array}$ & Endri (2011) \\
\hline 39 & JKP & $\begin{array}{l}\text { Pembiayaan Prinsip Bagi Hasil, Prinsip Jual } \\
\text { Beli Dan Prinsip Sewa Terhadap Falah Laba }\end{array}$ & Prasetyo (2011) \\
\hline 40 & JKP & $\begin{array}{l}\text { Peran Intermediasi Sosial Perbankan } \\
\text { Syariah: Inisiasi Pelayanan Keuangan Bagi } \\
\text { Masyarakat Miskin }\end{array}$ & $\begin{array}{l}\text { Antonio \& Nugraha } \\
\qquad(2012)\end{array}$ \\
\hline 41 & JKP & $\begin{array}{l}\text { Kinerja Keuangan Bank Dan Stabilitas } \\
\text { Makroekonomi Terhadap Profitabilitas } \\
\text { Bank Syariah Di Indonesia }\end{array}$ & Mukhlis (2012) \\
\hline 42 & $\mathrm{JKP}$ & $\begin{array}{l}\text { Permasalahan Pengembangan Sukuk } \\
\text { Korporasi Di Indonesia Menggunakan } \\
\text { Metode Analytical Network Process (ANP) }\end{array}$ & Endri (2009) \\
\hline 43 & $\mathrm{JKP}$ & $\begin{array}{l}\text { Cost Of Capital Pada Bank Syariah Mandiri } \\
\text { Periode 2004-2008 }\end{array}$ & $\begin{array}{c}\text { Setyawan \& Atahau } \\
(2010)\end{array}$ \\
\hline 44 & $\mathrm{JKP}$ & $\begin{array}{l}\text { Tingkat Suku Bunga Bank Konvensional } \\
\text { Dan Komitmen Nasabah Menabung Di } \\
\text { Bank Syariah }\end{array}$ & Yahya (2012) \\
\hline
\end{tabular}




\begin{tabular}{|c|c|c|c|}
\hline 45 & $\mathrm{JKP}$ & \begin{tabular}{|l} 
Sosialisasi Dan Persepsi Bank Syariah \\
(Kajian Kebijakan Enkulturasi Nilai-Nilai \\
Bank Syariah Dalam Masyarakat) \\
\end{tabular} & Sadhana (2012) \\
\hline 46 & JKP & $\begin{array}{l}\text { Determinan Return Saham Syariah Dengan } \\
\text { Risiko Sistematis Sebagai Variabel Mediasi }\end{array}$ & Firmansyah (2016) \\
\hline 47 & JKP & $\begin{array}{l}\text { Model Inovasi Sistem Pemasaran Perbankan } \\
\text { Syariah Berbasis Floating Market Untuk } \\
\text { Penciptaan Daya Saing (Model Of Islamic } \\
\text { Banking Marketing Innovation Systems } \\
\text { Based On Floating Market For Creation } \\
\text { Competitiveness) }\end{array}$ & Tobing Et Al. (2016) \\
\hline 48 & JKP & $\begin{array}{l}\text { Menyibak Agency Problem Pada Kontrak } \\
\text { Mudharabah Dan Alternatif Solusi }\end{array}$ & Maharani (2008) \\
\hline 49 & JKP & $\begin{array}{l}\text { Kepribadian Merek Dan Ikatan Emosional } \\
\text { Merek Terhadap Loyalitas Merek Tabungan } \\
\text { Bank Umum Syariah }\end{array}$ & Wahyuni (2015) \\
\hline 50 & JKP & $\begin{array}{l}\text { Early Warning System Dan Pertumbuhan } \\
\text { Pendapatan Kontribusi Pada Perusahaan } \\
\text { Asuransi Jiwa Syariah Di Indonesia }\end{array}$ & Oktaviani (2015) \\
\hline 51 & JKP & $\begin{array}{l}\text { Perbandingan Kualitas Layanan Bank } \\
\text { Syariah Dan Bank Konvensional } \\
\text { (Pendekatan Model PBZ) }\end{array}$ & $\begin{array}{l}\text { Choliq \& Misbach } \\
\text { (2016) }\end{array}$ \\
\hline 52 & $\mathrm{JKP}$ & $\begin{array}{l}\text { Sistem Peringatan Dini Sebagai Pendukung } \\
\text { Kinerja Perusahaan Asuransi Syariah }\end{array}$ & $\begin{array}{c}\text { Hasbi \& } \\
\text { Suryawardani (2013) }\end{array}$ \\
\hline 53 & JKP & $\begin{array}{l}\text { Pelaksanaan Pembiayaan Dana Talangan } \\
\text { Haji Pada Perbankan Syariah }\end{array}$ & $\begin{array}{l}\text { Susana \& Kartika } \\
\quad(2013)\end{array}$ \\
\hline 54 & $\mathrm{JKP}$ & $\begin{array}{l}\text { Efisiensi Pasar Modal Syariah Indonesia } \\
\text { Sebelum Dan Sesudah Krisis Finansial } \\
\text { Global } 2008\end{array}$ & Khajar (2012) \\
\hline 55 & JKP & $\begin{array}{l}\text { Pelaksanaan Dan Sistem Bagi Hasil } \\
\text { Pembiayaan Al-Mudharabah Pada Bank } \\
\text { Syariah }\end{array}$ & $\begin{array}{l}\text { Susana \& Prasetyanti } \\
\text { (2011) }\end{array}$ \\
\hline 56 & JKP & $\begin{array}{l}\text { Kaitan Kondisi Makroekonomi Dengan } \\
\text { Non Performing Financing Berdasarkan } \\
\text { Sektor Ekonomi Pada Perbankan Syariah Di } \\
\text { Indonesia }\end{array}$ & $\begin{array}{l}\text { Nuryartono Et Al. } \\
\quad(2016)\end{array}$ \\
\hline 57 & $\mathrm{JKP}$ & $\begin{array}{l}\text { Dampak Penetrasi Bank Asing Terhadap } \\
\text { Kinerja Keuangan Bank Islam Di Indonesia }\end{array}$ & Adawiyah (2015) \\
\hline 58 & $\mathrm{JKP}$ & $\begin{array}{l}\text { Praktek Quran-Based Human Resource } \\
\text { Management Di Perbankan Syariah } \\
\text { Berdasarkan Karakteristik Biografis }\end{array}$ & Asnawi Et Al. (2011) \\
\hline
\end{tabular}




\begin{tabular}{|c|c|c|c|}
\hline 59 & $\mathrm{JKP}$ & $\begin{array}{l}\text { Analisis Dan Evaluasi Mekanisme } \\
\text { Pelaksanaan Pembiayaan Al-Musyarakah } \\
\text { Pada Bank Syariah }\end{array}$ & Susana (2009) \\
\hline 60 & JKP & $\begin{array}{l}\text { Menelisik Makna Pembiayaan Qardhul } \\
\text { Hasan Dan Implementasinya Pada } \\
\text { Perbankan Syariah Di Indonesia } \\
\end{array}$ & $\begin{array}{l}\text { Falikhatun } E t A l \\
\qquad(2016)\end{array}$ \\
\hline 61 & JKP & $\begin{array}{l}\text { Kesepakatan Kelembagaan Kontrak } \\
\text { Mudharabah Dalam Kerangka Teori } \\
\text { Keagenan }\end{array}$ & Manzilati (2011) \\
\hline 62 & JKP & $\begin{array}{l}\text { Keunggulan Sistem Keuangan Berbasis Bagi } \\
\text { Hasil Dan Implikasinya Pada Distribusi } \\
\text { Pendapatan }\end{array}$ & Sugema Et Al (2009) \\
\hline 63 & JKP & $\begin{array}{l}\text { Pengujian Pecking Order Theory Pada } \\
\text { Emiten Syariah Di Bursa Efek Jakarta }\end{array}$ & $\begin{array}{l}\text { Setyawan \& Laksito } \\
\text { (2008) }\end{array}$ \\
\hline 64 & JKP & $\begin{array}{l}\text { Relationship Marketing Dan Loyalitas } \\
\text { Nasabah : Studi Pada Nasabah BRI Syariah } \\
\text { Malang }\end{array}$ & $\begin{array}{l}\text { Asnawi \& Musowir } \\
(2010)\end{array}$ \\
\hline 65 & JKP & $\begin{array}{l}\text { Daya Tarik Pasar Modal Islami: Studi Di } \\
\text { Bursa Efek Indonesia }\end{array}$ & Arifin (2014) \\
\hline 66 & JKP & $\begin{array}{l}\text { Measuring Efficiency As Intermediation } \\
\text { Approach Between Conventional And } \\
\text { Sharia Banks In Indonesia }\end{array}$ & $\begin{array}{c}\text { Al-Farisi \& } \\
\text { Hendrawan }(2010)\end{array}$ \\
\hline 67 & JKP & $\begin{array}{l}\text { Karakteristik Individu Dan Lingkungan } \\
\text { Kerja Terhadap Prestasi Kerja Karyawan } \\
\text { Bank Syariah }\end{array}$ & Susana (2009) \\
\hline 68 & JKP & $\begin{array}{l}\text { The Objective Of Islamic Bank: A Case } \\
\text { Study In Surakarta Region }\end{array}$ & Wijaya (2014) \\
\hline 69 & JKP & $\begin{array}{l}\text { Monetary Policy Shocks And Islamic Banks } \\
\text { Deposits In Indonesian Dual Banking } \\
\text { System After The Financial Crisis }\end{array}$ & $\begin{array}{l}\text { Affandi \& Tamanni } \\
\text { (2010) }\end{array}$ \\
\hline 70 & JKP & $\begin{array}{l}\text { Perbankan Syariah Di Indonesia Dan Peran } \\
\text { Perguruan Tinggi Dalam Rangka Akselerasi }\end{array}$ & Amalia (2010) \\
\hline 71 & JKP & $\begin{array}{l}\text { Pembiayaan Syariah Pada Usaha Mikro, } \\
\text { Kecil, Dan Menengah Sektor Agribisnis } \\
\text { Dengan Pola Kemitraan }\end{array}$ & Sutawi (2008) \\
\hline 72 & JKP & $\begin{array}{l}\text { Pengukuran Kesehatan Bank Syariah } \\
\text { Dengan Sharia Complience And } \\
\text { Performance }\end{array}$ & Sutrisno (2017) \\
\hline 73 & JEPI & $\begin{array}{l}\text { Pengukuran Kinerja Efisiensi Perbankan } \\
\text { Syariah : Analisis Empiris } 15 \text { Bank Syariah } \\
\text { Di Indonesia 2005-2007 }\end{array}$ & Endri (2010) \\
\hline
\end{tabular}




\begin{tabular}{|c|c|c|c|}
\hline 74 & JEPI & $\begin{array}{l}\text { Perbandingan Profitabilitas Industri } \\
\text { Perbankan Syariah Dan Industri Perbankan } \\
\text { Konvensional Menggunakan Metode } \\
\text { Struktur Kinerja Dan Perilaku }\end{array}$ & $\begin{array}{l}\text { Amalia \& Nasution } \\
(2007)\end{array}$ \\
\hline 75 & JEPI & $\begin{array}{l}\text { Profit Sharing Dan Moral Hazard Dalam } \\
\text { Penyaluran Dana Pihak Ketiga Bank Umum } \\
\text { Syariah Di Indonesia }\end{array}$ & $\begin{array}{l}\text { Nasution \& Wiliasih } \\
(2007)\end{array}$ \\
\hline 76 & JEPI & $\begin{array}{l}\text { Analisis Persaingan Bank Syariah Indonesia : } \\
\text { Aplikasi Model Panzar-Rosse }\end{array}$ & Kasri \& Iman (2010) \\
\hline 77 & Ventura & $\begin{array}{l}\text { Determinants Of Customers In Selecting } \\
\text { Sharia Banking System For Saving In East } \\
\text { Java - Indonesia }\end{array}$ & Mariyono (2012) \\
\hline 78 & Ventura & $\begin{array}{l}\text { The Effect Of Audit Committee Role And } \\
\text { Sharia Supervisory Board Role On Financial } \\
\text { Reporting Quality At Islamic Banks In } \\
\text { Indonesia }\end{array}$ & Rini (2014) \\
\hline 79 & Ventura & $\begin{array}{l}\text { Analysis Of Donor's Trust And Relationship } \\
\text { Commitment In Lembaga Amil Zakat In } \\
\text { Indonesia }\end{array}$ & Handriana (2016) \\
\hline 80 & Ventura & $\begin{array}{l}\text { Determining The Optimum Portfolio Of } \\
\text { Shariah Stocks Using An Approach Of } \\
\text { Shariah Compliant Asset Pricing Model } \\
\text { (SCAPM) }\end{array}$ & $\begin{array}{l}\text { Husein \& Hasanah } \\
\text { (2016) }\end{array}$ \\
\hline 81 & Ventura & $\begin{array}{l}\text { Profit Efficiency Of Shariah Banks In } \\
\text { Indonesia And The Determining Factors: } \\
\text { Using Stochastic Frontier Analysis Method }\end{array}$ & $\begin{array}{l}\text { Wahyuni \& Pujiharto } \\
\qquad(2016)\end{array}$ \\
\hline 82 & Ventura & $\begin{array}{l}\text { The Islamic Capital Market Response To } \\
\text { The Real Earnings Management }\end{array}$ & $\begin{array}{l}\text { Yuliana \& Alim } \\
\qquad(2017)\end{array}$ \\
\hline 83 & Ventura & $\begin{array}{l}\text { State Sukuk Potential In Reducing } \\
\text { Indonesia Budget Deficit 2009 - } 2015\end{array}$ & $\begin{array}{l}\text { Amaliah \& Aspiranti } \\
\text { (2017) }\end{array}$ \\
\hline 84 & Ventura & $\begin{array}{l}\text { Analysis Of Factors Affecting The } \\
\text { Disclosure Of Islamic Social Reporting (An } \\
\text { Empirical Study On The Sharia Securities } \\
\text { List) }\end{array}$ & $\begin{array}{l}\text { Nugraheni \& } \\
\text { Wijayanti (2017) }\end{array}$ \\
\hline 85 & Iqtishadia & $\begin{array}{l}\text { Pengaruh Biaya, Angsuran Dan Kualitas } \\
\text { Pelayanan Terhadap Kepuasan Nasabah } \\
\text { Pembiayaan BMT Di Kabupaten Kudus }\end{array}$ & Rokhman (2016) \\
\hline 86 & Iqtishadia & $\begin{array}{l}\text { Metode Spin-Off Dan Tingkat Profitabilitas } \\
\text { : Studi Pada Bank Umum Syariah Hasil } \\
\text { Spin-Off }\end{array}$ & $\begin{array}{l}\text { Arif \& Derwanti } \\
\text { (2017) }\end{array}$ \\
\hline 87 & Iqtishadia & $\begin{array}{l}\text { Studi Eksplorasi Penerapan Etika Bisnis } \\
\text { Pada Perbankan Syari'ah Di Indonesia }\end{array}$ & Rahayu (2017) \\
\hline
\end{tabular}




\begin{tabular}{|c|c|c|c|}
\hline 88 & Iqtishadia & $\begin{array}{l}\text { Studi Komparasi Kinerja Bank Perkreditan } \\
\text { Rakyat (BPR) Syariah Dan Konvensional } \\
\text { Di Sumatera Barat }\end{array}$ & Hamidi (2017) \\
\hline 89 & Iqtishadia & $\begin{array}{l}\text { Determinan Dana Pihak Ketiga Bank } \\
\text { Syariah Di Indonesia: Model Vector } \\
\text { Autoregresive }\end{array}$ & Harahap (2017) \\
\hline 90 & Iqtishadia & $\begin{array}{l}\text { Analisis Solutif Penyelesaian Pembiayaan } \\
\text { Bermasalah Di Bank Syariah: Kajian Pada } \\
\text { Produk Murabahah Di Bank Muamalat } \\
\text { Indonesia Banda Aceh }\end{array}$ & $\begin{array}{c}\text { Ibrahim \& Rahmati } \\
\text { (2017) }\end{array}$ \\
\hline 91 & Iqtishadia & $\begin{array}{l}\text { Pengaruh Kualitas Pelayanan B2B } \\
\text { Perbankan Syari'ah Dan Cultural Fit Pada } \\
\text { Kepuasan, Loyalitas, Dan Rekomendasi } \\
\text { Positif }\end{array}$ & Rahayu (2016) \\
\hline 92 & Iqtishadia & $\begin{array}{l}\text { Pengaruh Belanja Pemerintah Dan } \\
\text { Pembiayaan Bank Syariah Terhadap } \\
\text { Pertumbuhan Ekonomi: Studi Kasus Data } \\
\text { Panel Provinsi Di Indonesia }\end{array}$ & Ananto (2017) \\
\hline 93 & Iqtishadia & $\begin{array}{l}\text { Pengaruh Pembiayaan Murabahah, } \\
\text { Musyarakah, Dan Biaya Transaksi Terhadap } \\
\text { Profitabilitas Bank Pembiayaan Rakyat } \\
\text { Syariah }\end{array}$ & $\begin{array}{c}\text { Agza \& Darwanto } \\
(2017)\end{array}$ \\
\hline 94 & Iqtishadia & $\begin{array}{l}\text { The Impact Of Good Corporate } \\
\text { Governance, Company Size Nn Corporate } \\
\text { Social Responsibility Disclosure: Case Study } \\
\text { Of Islamic Banking In Indonesia }\end{array}$ & Qoyum Et Al (2017) \\
\hline 95 & Iqtishadia & $\begin{array}{l}\text { Budaya Organisasi Islami Sebagai Upaya } \\
\text { Meningkatkan Kinerja }\end{array}$ & Hakim (2016) \\
\hline 96 & Iqtishadia & $\begin{array}{l}\text { Analisis Faktor-Faktor Sustainabilitas } \\
\text { Lembaga Keuangan Mikro Syariah }\end{array}$ & Zubair (2016) \\
\hline 97 & Iqtishadia & $\begin{array}{l}\text { Penyelesaian Pembiayaan Murabahah } \\
\text { Bermasalah Di Baitul Maal Wa Tamwil } \\
(\text { BMT) }\end{array}$ & Shobirin (2016) \\
\hline 98 & Iqtishadia & $\begin{array}{l}\text { Fakta Empirik Tentang Etos Kerja Islam, } \\
\text { Stres Kerja, Kepuasan Kerja, Dan Kinerja } \\
\text { Akuntan Pada Industri Keuangan Islam Di } \\
\text { Indonesia }\end{array}$ & Amilin (2016) \\
\hline 99 & Iqtishadia & $\begin{array}{l}\text { Peran Bank Indonesia, Dewan Syariah } \\
\text { Nasional, Badan Wakaf Indonesia Dan } \\
\text { Baznas Dalam Pengembangan Produk } \\
\text { Hukum Ekonomi Islam Di Indonesia } \\
\end{array}$ & Iswanto (2016) \\
\hline 100 & Iqtishadia & $\begin{array}{l}\text { Filantropi Islam Untuk Pemberdayaan } \\
\text { Ekonomi Umat (Model Pemberdayaan } \\
\text { ZISWAF Di BMT Se-Kabupaten Demak) }\end{array}$ & Kasdi (2016) \\
\hline
\end{tabular}




\begin{tabular}{|c|c|l|c|}
\hline 101 & Iqtishadia & $\begin{array}{l}\text { Faktor-Faktor Yang Mempengaruhi Tingkat } \\
\text { Profitabilitas Bank Pembiayaan Rakyat } \\
\text { Syariah (BPRS) Di Aceh }\end{array}$ & $\begin{array}{c}\text { Yusuf \& Mahriana } \\
\text { (2016) }\end{array}$ \\
\hline
\end{tabular}

Appendix 2. List of Sample Articles (Continued)

\begin{tabular}{|c|c|c|c|}
\hline 102 & Iqtishadia & $\begin{array}{l}\text { Pergerakan Bersama Indeks Pasar } \\
\text { Saham Syariah Dan Variabel Makro } \\
\text { Ekonomi: Pendekatan Regime- } \\
\text { Switching Regression }\end{array}$ & Wibowo (2017) \\
\hline 103 & Iqtishadia & $\begin{array}{l}\text { Aplikasi Model Bisnis Microfinance } \\
\text { Syariah Terhadap Sektor UMKM Di } \\
\text { Indonesia }\end{array}$ & Effendi Et Al. (2017) \\
\hline 104 & Iqtishadia & $\begin{array}{l}\text { Analisis Perbandingan Kinerja } \\
\text { Reksa Dana Saham Syariah Dan } \\
\text { Konvensional Periode 2012-2015 }\end{array}$ & Huda Et Al (2017) \\
\hline 105 & Iqtishadia & $\begin{array}{l}\text { Exploring Strategies To Enhance } \\
\text { Islamic Banking's Role To Raise Cash } \\
\text { Wagf Funds }\end{array}$ & $\begin{array}{l}\text { Khairunisa Et Al. } \\
\qquad(2017)\end{array}$ \\
\hline 106 & Iqtishadia & $\begin{array}{l}\text { The Impact Of Macroeconomic On } \\
\text { Nonperforming Loan: Comparison } \\
\text { Study At Conventional And Islamic } \\
\text { Banking }\end{array}$ & $\begin{array}{l}\text { Kusmayadi Et Al. } \\
(2017)\end{array}$ \\
\hline 107 & Signifikan & $\begin{array}{l}\text { Islamic Bond: An Alternative To Local } \\
\text { Government Financing }\end{array}$ & Rahmayati (2016) \\
\hline 108 & Signifikan & $\begin{array}{l}\text { Islamic Stocks Index Performance: } \\
\text { Comparative Studies Between } \\
\text { Indonesia And Malaysia }\end{array}$ & $\begin{array}{c}\text { Tulasmi \& } \\
\text { Trihariyanto }(2016)\end{array}$ \\
\hline 109 & Signifikan & $\begin{array}{l}\text { Islamic Group Lending And Financial } \\
\text { Inclusion }\end{array}$ & $\begin{array}{l}\text { Rusydiana \& Devi } \\
(2016)\end{array}$ \\
\hline 110 & Signifikan & $\begin{array}{l}\text { Islamic Banking Efficiency: } \\
\text { Comparative Studies Between Malaysia } \\
\text { And Indonesia }\end{array}$ & Yulita \& Rizal (2016) \\
\hline 111 & Signifikan & $\begin{array}{l}\text { Determinant Of The Poverty In The } \\
\text { Moslem Countries: Ibn Khaldun } \\
\text { Development Model }\end{array}$ & Putra \& Indra (2016) \\
\hline 112 & Signifikan & $\begin{array}{l}\text { The Motivation Of Muzakki To Pay } \\
\text { Zakah: Study At The Baitul Mal Aceh }\end{array}$ & Majid (2017) \\
\hline 113 & Signifikan & $\begin{array}{l}\text { Islamic Microfinance And Its Impact } \\
\text { On Poverty Reduction In Bogor }\end{array}$ & $\begin{array}{l}\text { Sabiti \& Effendi } \\
(2017)\end{array}$ \\
\hline 114 & Signifikan & $\begin{array}{l}\text { Liquidity And Capital Of Islamic } \\
\text { Banks In Indonesia }\end{array}$ & $\begin{array}{l}\text { Hosen \& Muhari } \\
\text { (2017) }\end{array}$ \\
\hline
\end{tabular}




\begin{tabular}{|c|c|c|c|}
\hline 115 & Signifikan & $\begin{array}{l}\text { Merger And Industrial Acceleration: } \\
\text { Study At Indonesian Islamic Banking } \\
\text { Industry }\end{array}$ & $\begin{array}{c}\text { Miftah \& Wibowo } \\
(2017)\end{array}$ \\
\hline 116 & Al-Iqtishad & $\begin{array}{l}\text { Pengaruh Indeks Harga Saham Syariah } \\
\text { Internasional Dan Variabel Makro } \\
\text { Ekonomi Terhadap Jakarta Islamic } \\
\text { Index }\end{array}$ & $\begin{array}{l}\text { Beik \& Fatmawati } \\
(2014)\end{array}$ \\
\hline 117 & Al-Iqtishad & $\begin{array}{l}\text { Komparasi Efisiensi Teknis Bank } \\
\text { Umum Konvensional (BUK) Dan } \\
\text { Bank Umum Syariah (BUS) Di } \\
\text { Indonesia Dengan Metode Data } \\
\text { Envelopment Analysis (DEA) } \\
\end{array}$ & Wahab Et Al. (2014) \\
\hline 118 & Al-Iqtishad & $\begin{array}{l}\text { Perbandingan Kinerja Instrumen } \\
\text { Investasi Berbasis Syariah Dengan } \\
\text { Konvensional Pada Pasar Modal Di } \\
\text { Indonesia }\end{array}$ & Syafrida Et Al. (2014) \\
\hline 119 & Al-Iqtishad & Volatility Of Jakarta Islamic Index & Tanjung (2014) \\
\hline 120 & Al-Iqtishad & \begin{tabular}{|l} 
Prioritas Solusi Permasalahan \\
Pengelolaan Zakat Dengan Metode \\
AHP (Studi Di Banten Dan \\
Kalimantan Selatan) \\
\end{tabular} & Huda Et Al (2014) \\
\hline 121 & Al-Iqtishad & $\begin{array}{l}\text { Analisis Faktor Kualitas Pelayanan Di } \\
\text { Bank Syariah }\end{array}$ & Suryani (2014) \\
\hline 122 & Al-Iqtishad & $\begin{array}{l}\text { Kritik Ilmu Ekonomi Strukturalis Dan } \\
\text { Islam Terhadap Ekonomi Neoklasikal }\end{array}$ & Risza (2014) \\
\hline 123 & Al-Iqtishad & $\begin{array}{l}\text { Analisis Stabilitas Dinar Emas Dan } \\
\text { Dolar AS Dalam Denominasi Rupiah }\end{array}$ & Harahap (2014) \\
\hline 124 & Al-Iqtishad & $\begin{array}{l}\text { The Critical Aspect On Fair Value } \\
\text { Accounting And Its Implication To } \\
\text { Islamic Financial Institutions }\end{array}$ & $\begin{array}{l}\text { Majid \& Haliding } \\
\qquad(2014)\end{array}$ \\
\hline 125 & Al-Iqtishad & $\begin{array}{l}\text { Faktor-Faktor Yang Mempengaruhi } \\
\text { Persepsi Nazhir Terhadap Wakaf Uang }\end{array}$ & Dahlan (2014) \\
\hline 126 & Al-Iqtishad & $\begin{array}{l}\text { The Need For The Islamization Of } \\
\text { Knowledge In Accounting }\end{array}$ & $\begin{array}{c}\text { Majid \& Haliding } \\
(2014)\end{array}$ \\
\hline 127 & Al-Iqtishad & $\begin{array}{l}\text { Analisis Kesesuaian Konstitusi } \\
\text { Ekonomi Indonesia Terhadap Ekonomi } \\
\text { Islam }\end{array}$ & $\begin{array}{c}\text { Rama \& Makhlani } \\
(2014)\end{array}$ \\
\hline 128 & Al-Iqtishad & $\begin{array}{l}\text { Pengaruh Rentabilitas, Efisiensi Dan } \\
\text { Likuiditas Terhadap Kecukupan Modal } \\
\text { Bank Umum Syariah }\end{array}$ & Fatimah (2014) \\
\hline 129 & Al-Iqtishad & $\begin{array}{l}\text { Pengaruh Dana Investasi Melalui } \\
\text { Instrumen SUN Dan SBSN Terhadap } \\
\text { Pertumbuhan Ekonomi Indonesia } \\
\end{array}$ & Ryandini (2014) \\
\hline
\end{tabular}

Vol. 4 No. 1, January - April 2019 


\begin{tabular}{|c|c|c|c|}
\hline 130 & Al-Iqtishad & $\begin{array}{l}\text { Efektivitas Layanan Weekend Banking } \\
\text { (Studi Bank Muamalat KCP Pondok } \\
\text { Indah Mall) }\end{array}$ & Farhah (2014) \\
\hline 131 & Al-Iqtishad & Pengelolaan Likuiditas Bank Syariah & Ichsan (2014) \\
\hline 132 & Al-Iqtishad & $\begin{array}{l}\text { Pengaruh Biaya Promosi Terhadap } \\
\text { Peningkatan Jumlah Peserta Asuransi: } \\
\text { Studi Di AJB Bumiputera } 1912 \text { Divisi } \\
\text { Syariah }\end{array}$ & Salamudin (2014) \\
\hline 133 & Al-Iqtishad & $\begin{array}{l}\text { Etika Bisnis Islam: Konsep Dan } \\
\text { Implementasi Pada Pelaku Usaha Kecil }\end{array}$ & Amalia (2014) \\
\hline 134 & Al-Iqtishad & $\begin{array}{l}\text { Peran Etika Qur'ani Terhadap Sistem } \\
\text { Ekonomi Islam }\end{array}$ & Iswandi (2014) \\
\hline 135 & Al-Iqtishad & $\begin{array}{l}\text { Mapping And Correlation Analysis Of } \\
\text { Efficiency And Profitability: The Case } \\
\text { Of Islamic Rural Bank In Indonesia }\end{array}$ & $\begin{array}{l}\text { Warninda \& Hosen } \\
\qquad(2015)\end{array}$ \\
\hline 136 & Al-Iqtishad & $\begin{array}{l}\text { Human Resources Development Of } \\
\text { Sharia Banking: Phenomenological } \\
\text { Approach }\end{array}$ & Yusuf (2015) \\
\hline 137 & Al-Iqtishad & $\begin{array}{l}\text { Financial Ratio And Its Influence To } \\
\text { Profitability In Islamic Banks }\end{array}$ & Amelia (2015) \\
\hline 138 & Al-Iqtishad & $\begin{array}{l}\text { The Image Of Financial Institution } \\
\text { As Islamic Bank In Mediation Service } \\
\text { Quality And Customer Satisfaction On } \\
\text { Customer Loyalty In Purwokerto }\end{array}$ & Warsito (2015) \\
\hline 139 & Al-Iqtishad & $\begin{array}{l}\text { The Influences Of Productive Zakah } \\
\text { Mentoring To The Saving Behavior } \\
\text { And The Prosperity Of Poor Housewife }\end{array}$ & $\begin{array}{l}\text { Andriati \& Huda } \\
\text { (2015) }\end{array}$ \\
\hline 140 & Al-Iqtishad & $\begin{array}{l}\text { The Intellectual Capital Effect On } \\
\text { Financial Performances At Islamic } \\
\text { Insurance }\end{array}$ & $\begin{array}{l}\text { Aji \& Kurniasih } \\
(2015)\end{array}$ \\
\hline 141 & Al-Iqtishad & $\begin{array}{l}\text { Peer Group Effects On Moslem } \\
\text { Consumer's Decision To Purchase } \\
\text { Halal-Labeled Cosmetics }\end{array}$ & Aisyah (2015) \\
\hline 142 & Al-Iqtishad & $\begin{array}{l}\text { Effects Of Service Quality, Customer } \\
\text { Trust And Customer Religious } \\
\text { Commitment On Customer } \\
\text { Satisfaction And Loyalty Of Islamic } \\
\text { Banks In East Java }\end{array}$ & $\begin{array}{l}\text { Hidayat Et Al. } \\
\quad(2015)\end{array}$ \\
\hline 143 & Al-Iqtishad & $\begin{array}{l}\text { The Impact Of Financial Liberalization } \\
\text { On Islamic Bank's Efficiency In } \\
\text { Indonesia }\end{array}$ & Adawiyah (2015) \\
\hline 144 & Al-Iqtishad & $\begin{array}{l}\text { Measurement Of Shariah Stock } \\
\text { Performance Using Risk Adjusted } \\
\text { Performance }\end{array}$ & $\begin{array}{l}\text { Yunan \& Rahmasari } \\
\text { (2015) }\end{array}$ \\
\hline
\end{tabular}




\begin{tabular}{|c|c|c|c|}
\hline 145 & Al-Iqtishad & $\begin{array}{l}\text { Construction Of Cibest Model As } \\
\text { Measurement Of Poverty And Welfare } \\
\text { Indices From Islamic Perspective }\end{array}$ & $\begin{array}{l}\text { Beik \& Arsyianti } \\
\qquad(2015)\end{array}$ \\
\hline 146 & Al-Iqtishad & $\begin{array}{l}\text { Macroeconomic Variable And Its } \\
\text { Influence On Performance Of } \\
\text { Indonesian Islamic Banking }\end{array}$ & Pratama (2015) \\
\hline 147 & Al-Iqtishad & $\begin{array}{l}\text { A Developing Model Of Relationship } \\
\text { Among Service Quality, Consumer } \\
\text { Satisfaction, Loyalty And Word Of } \\
\text { Mouth In Islamic Banking }\end{array}$ & $\begin{array}{l}\text { Suryani \& Hendryadi } \\
\text { (2015) }\end{array}$ \\
\hline 148 & Al-Iqtishad & $\begin{array}{l}\text { The Role Of Religious Norms On } \\
\text { Selecting The Islamic Bank }\end{array}$ & Usman (2015) \\
\hline 149 & Al-Iqtishad & $\begin{array}{l}\text { Evaluating The Models Of Sharia } \\
\text { Microfinance In Indonesia: An } \\
\text { Analytical Network Process (Anp) } \\
\text { Approach }\end{array}$ & $\begin{array}{l}\text { Amalia \& Atiqah } \\
\qquad(2015)\end{array}$ \\
\hline 150 & Al-Iqtishad & $\begin{array}{l}\text { Application Of Pattern Of Islamic } \\
\text { State Revenue Policy To Improve The } \\
\text { Ability Of Indonesia's Fiscal }\end{array}$ & Setianingrum (2015) \\
\hline 151 & Al-Iqtishad & $\begin{array}{l}\text { The Impact Of Spin-Off Policy To The } \\
\text { Profitability On Indonesian Islamic } \\
\text { Banking Industry }\end{array}$ & Hamid (2015) \\
\hline 152 & Al-Iqtishad & $\begin{array}{l}\text { The Short-Run And Long-Run } \\
\text { Relationship In Indonesian Islamic } \\
\text { Stock Returns }\end{array}$ & Madjid (2016) \\
\hline 153 & Al-Iqtishad & $\begin{array}{l}\text { Business Process Reengineering Of } \\
\text { Funding On Indonesia's Islamic Banks }\end{array}$ & $\begin{array}{l}\text { Widigdo Et Al. } \\
\qquad(2016)\end{array}$ \\
\hline 154 & Al-Iqtishad & $\begin{array}{l}\text { Efficiency And Profitability On } \\
\text { Indonesian Islamic Banking Industry }\end{array}$ & $\begin{array}{c}\text { Hosen \& Rahmawati } \\
\text { (2016) }\end{array}$ \\
\hline 155 & Al-Iqtishad & $\begin{array}{l}\text { Islamic Work Ethics And Audit } \\
\text { Opinions: Audit Professionalism And } \\
\text { Dysfunctional Behavior As Intervening } \\
\text { Variables }\end{array}$ & Suryanto (2016) \\
\hline 156 & Al-Iqtishad & $\begin{array}{l}\text { Dual Monetary System And } \\
\text { Macroeconomic Performance In } \\
\text { Indonesia }\end{array}$ & $\begin{array}{l}\text { Herianingrum \& } \\
\text { Syapriatama }(2016)\end{array}$ \\
\hline 157 & Al-Iqtishad & $\begin{array}{l}\text { Islamic Business Ethics } \\
\text { Implementation In Marketing } \\
\text { Communication Of Hajj/Umroh } \\
\text { Travel Agency "X" Surabaya }\end{array}$ & $\begin{array}{l}\text { Prasetyo \& Pratiwi } \\
\text { (2016) }\end{array}$ \\
\hline 158 & Al-Iqtishad & $\begin{array}{l}\text { Risk Of Profit Loss Sharing Financing: } \\
\text { The Case Of Indonesia }\end{array}$ & Ernawati (2016) \\
\hline
\end{tabular}

Vol. 4 No. 1, January - April 2019 


\begin{tabular}{|c|c|c|c|}
\hline 159 & Al-Iqtishad & $\begin{array}{l}\text { The Development Of Human } \\
\text { Resources In Islamic Financial } \\
\text { Industries From Economic And Islamic } \\
\text { Financial Graduates }\end{array}$ & Huda Et Al. (2016) \\
\hline 160 & Al-Iqtishad & $\begin{array}{l}\text { Application Of Theory Reasoned } \\
\text { Action In Intention To Use Islamic } \\
\text { Banking In Indonesia }\end{array}$ & $\begin{array}{l}\text { Reni \& Ahmad } \\
\quad(2016)\end{array}$ \\
\hline 161 & Al-Iqtishad & $\begin{array}{l}\text { The Effect Of Social Capital On Custo } \\
\text { Mer's Repayment Rate At Islamic } \\
\text { Microfinance Institution }\end{array}$ & $\begin{array}{l}\text { Effendi \& Utami } \\
\qquad(2016)\end{array}$ \\
\hline 162 & Al-Iqtishad & $\begin{array}{l}\text { Determinants Of Liquidity Risk In } \\
\text { Indonesian Islamic And Conventional } \\
\text { Banks }\end{array}$ & $\begin{array}{c}\text { Sukmana } \& \\
\text { Suryaningtyas }(2016)\end{array}$ \\
\hline 163 & Al-Iqtishad & $\begin{array}{l}\text { The Efficiency Of Zakah Institutions } \\
\text { Using Data Envelopment Analysis }\end{array}$ & $\begin{array}{c}\text { Rusydiana \& Al-Farisi } \\
\text { (2016) }\end{array}$ \\
\hline 164 & Al-Iqtishad & $\begin{array}{l}\text { Shari'ah-Compliant E-Commerce } \\
\text { Models And Consumer Trust }\end{array}$ & $\begin{array}{l}\text { Ardiansyarh Et Al. } \\
\text { (2016) }\end{array}$ \\
\hline 165 & Al-Iqtishad & $\begin{array}{l}\text { Effectiveness Of Zakah Targeting In } \\
\text { Alleviating Poverty In Indonesia }\end{array}$ & Kasri (2016) \\
\hline 166 & Al-Iqtishad & $\begin{array}{l}\text { The Patronage Behaviour Of Islamic } \\
\text { Bank’s Customers: Empirical Studies } \\
\text { In Aceh }\end{array}$ & $\begin{array}{l}\text { Majid \& Zulhanizar } \\
\quad(2016)\end{array}$ \\
\hline 167 & Al-Iqtishad & $\begin{array}{l}\text { Determinant Of The Corporate } \\
\text { Environmental Disclosure: Study On } \\
\text { Jakarta Islamic Index }\end{array}$ & $\begin{array}{l}\text { Yulianti,Suzanawaty, } \\
\text { Putri \& Haribowo } \\
\text { (2016) }\end{array}$ \\
\hline 168 & Al-Iqtishad & $\begin{array}{l}\text { Risk And Return: Bonds And Sukuk In } \\
\text { Indonesia }\end{array}$ & $\begin{array}{l}\text { Rodoni \& Setiawan } \\
\text { (2016) }\end{array}$ \\
\hline 169 & Al-Iqtishad & $\begin{array}{l}\text { Islamic Prayer, Spirituality, And } \\
\text { Productivity: An Exploratory } \\
\text { Conceptual Analysis }\end{array}$ & Al Haq Et Al. (2016) \\
\hline 170 & Al-Iqtishad & $\begin{array}{l}\text { Islamic Banks Service Innovation } \\
\text { Quality: Conceptual Model }\end{array}$ & Khan (2016) \\
\hline 171 & Al-Iqtishad & $\begin{array}{l}\text { Consumers Demand On Halal } \\
\text { Cosmetics And Personal Care Products } \\
\text { In Indonesian }\end{array}$ & Aisyah (2017) \\
\hline 172 & Al-Iqtishad & $\begin{array}{l}\text { Tawhidic Based Economic System: A } \\
\text { Preliminary Conception }\end{array}$ & $\begin{array}{l}\text { Hilmiyah Et Al. } \\
\text { (2017) }\end{array}$ \\
\hline 173 & Al-Iqtishad & $\begin{array}{l}\text { Determinants Of The Islamic Social } \\
\text { Reporting Disclosure }\end{array}$ & $\begin{array}{c}\text { Sunarsih } \& \\
\text { Ferdiyansyah }(2017) \\
\end{array}$ \\
\hline 174 & Al-Iqtishad & $\begin{array}{l}\text { Building An Early Warning Towards } \\
\text { The Resilience Of Islamic Banking In } \\
\text { Indonesia }\end{array}$ & $\begin{array}{l}\text { Wiranatakusuma \& } \\
\text { Duasa }(2017)\end{array}$ \\
\hline
\end{tabular}




\begin{tabular}{|c|c|c|c|}
\hline 175 & Al-Iqtishad & $\begin{array}{l}\text { Strategic Approach For Optimizing } \\
\text { Of Zakah Institution Performance: } \\
\text { Customer Relationship Management }\end{array}$ & $\begin{array}{l}\text { Widarwati Et Al/ } \\
\text { (2017) }\end{array}$ \\
\hline 176 & Al-Iqtishad & $\begin{array}{l}\text { Islamic Bank Listed In Financial } \\
\text { Market: Risk, Governance, Earning, } \\
\text { And Capital }\end{array}$ & $\begin{array}{l}\text { Budiman Et Al. } \\
\quad(2017)\end{array}$ \\
\hline 177 & Al-Iqtishad & $\begin{array}{l}\text { The Indonesian Islamic Bank's Spin- } \\
\text { Off: A Study In Regional Development } \\
\text { Banks }\end{array}$ & Haribowo (2017) \\
\hline 178 & Al-Iqtishad & $\begin{array}{l}\text { Bankruptcy Model Analysis: } \\
\text { Comparative Studies Between Sharia } \\
\text { And Non Sharia Manufacturing } \\
\text { Companies }\end{array}$ & Ruhadi \& Mai (2017) \\
\hline 179 & Al-Iqtishad & $\begin{array}{l}\text { Currency System And It's Impact On } \\
\text { Economic Stability }\end{array}$ & $\begin{array}{l}\text { Saharuddin \& Rama } \\
\text { (2017) }\end{array}$ \\
\hline 180 & Al-Iqtishad & $\begin{array}{l}\text { Risk Of Debt-Based Financing In } \\
\text { Indonesian Islamic Banking }\end{array}$ & Effendi (2017) \\
\hline 181 & Al-Iqtishad & $\begin{array}{l}\text { Islamic Banking Existence And } \\
\text { Domestic Credit: Study At Seven } \\
\text { Countries }\end{array}$ & $\begin{array}{l}\text { Yuafi \& Bawono } \\
\text { (2017) }\end{array}$ \\
\hline 182 & Al-Iqtishad & $\begin{array}{l}\text { Comparing Efficiency And } \\
\text { Productivity In Islamic Banking: Case } \\
\text { Study In Indonesia, Malaysia And } \\
\text { Pakistan }\end{array}$ & Rodoni Et Al. (2017) \\
\hline 183 & Al-Iqtishad & $\begin{array}{l}\text { Determining Factors Of Deposit Level } \\
\text { Of Islamic Bank In Indonesia }\end{array}$ & $\begin{array}{c}\text { Baehaqie Et Al. } \\
(2017)\end{array}$ \\
\hline 184 & Al-Iqtishad & $\begin{array}{l}\text { Fatwa And The Development Of } \\
\text { Sharia Financial Industry: A Lesson } \\
\text { From Indonesia }\end{array}$ & Amin (2017) \\
\hline
\end{tabular}

Vol. 4 No. 1, January - April 2019 


\section{Shirkah Author Guidelines}

Shirkab currently offers two routes to submit manuscripts. We highly recommend to submit the articles which are made using OJS (Open Journal System). Feel free register as author soon through visiting http://shirkah. or.id/index.php/home/user/register. The authors may directly send their manuscripts, along with their resume, to shirkahiainsurakarta@gmail. com. Please prepare your manuscripts, using following guidelines:

1. Manuscript must be written in English. Submitted articles should not have been published or be under review for publication with another journal.

2. Manuscript's length is about $15-20$ pages, typed in one-half spaced on A4-paper size.

3. Manuscript must include an $150-200$ word abstract and keywords.

4. Manuscript must be arranged as follows: Title, Name of Author, E-mail address, Abstract, Keywords, Introduction (including method if any), Discussion, Conclusion, References.

5. Manuscript's titles not more than ten words.

6. Manuscript must be submitted in Microsoft Word or RTF.

7. Arabic words should be transliterated according to the style of International Journal of Middle Eastern Studies.

8. Manuscript references are preferably derived from the up-to-date references.

9. The author's resume should be submitted separately, consisting of at least full name, institutional address, phone number, areas of studies, and recent publications (if any).

10. Shirkab use APA Style 6th edition (2010) as reference format writing. We suggest the use of a reference manager software such as Mendeley, Zotero, and Endnote at templating the citation style. APA Style to be used is as follows: 


\section{Book with single author}

Swann, G. M. Peter. (2014). The Economics of Innovation an Introduction. Cheltenhum \& Northampton: Edward Elgar.

in-text citation: (Swann, 2014)

\section{Articles in reference books}

Alatas, S. F. (2006). Islam and the Science of Economics in Abu Rabi', I.M. The Blackwell Companion to Contemporary Islamic Thought. USA: Willey-Blackwell (pp. 587-606).

in text citation: (Alatas, 2006)

\section{E-Book}

Hackett, Rosalind (2007). "Religous Dimentions of War and Peace: Introduction." Dalam Gerrie ter Haar dan Yoshio Tsuruoka (Ed.), Religion and Society: An Agenda for the 21st Century (h. 3-6). Retrieved from http:// brill.nl.

in text citation: (Hackett, 2006)

\section{Master's thesis, from a commercial database}

McNieI, D. S. (2006). Meaning through narrative: A personal narrative discussing growing up with an alcoholic mother (Master's thesis). Available from ProQuest Dissertations and Theses database. (UMI No. 1434728)

in text citation: (Mc Niel, 2006)

\section{Doctoral dissertation, from an institutional database}

Adams, R. J. (1973). Building a foundation for evaluation of instruction in higher education and continuing education (Doctoral dissertation). Retrieved from http://www.ohiolink.edu/etd/

in text citation: (Adams, 1973) 


\section{Doctoral dissertation, from the web}

Bruckman, A. (1997). MOOSE Crossing: Construction, community, and learning in a networked virtual world for kids (Doctoral dissertation, Massachusetts Institute of Technology). Retrieved from http:/www-static. cc.gatech.edu/--asb/thesis/

in text citation: (Bruckman, 1997)

\section{Journal article with No DOI}

Bourkhis, K., and Nabi, M. S. (2013). Islamic and conventional banks' soundness during the 2007-2008 financial crisis. Journal Metrics, 22(2), 68-77.

in-text citation: (Bourkhis \& Nabi, 2013).

\section{Journal article with DOI}

Ichwan, M. (2012). The Local Politics Of Orthodoxy: The Majelis Ulama Indonesia in the Post-New Order Banten. Journal Of Indonesian Islam, 6(1), 166-194. doi:http://dx.doi.org/10.15642/JIIS.2012.6.1.166-194

In text citation : (Ichwan, 2012)

\section{Abstract as citation}

Hasan, N. (2012). Islamist Party, Electoral Politics And Da'wah Mobilization Among Youth : The Prosperous Justice Party (PKS) in Indonesia. Journal of Indonesian Islam, 6(1), 17-47. Abstract from http://jiis.uinsby. ac.id/index.php/jiis/article/view/97

in text citation : (Hasan, 2012)

\section{Mass media article}

Sahal, Akhmad (2014, March 2). Kiai Sahal dan Realisme Fikih.Tempo Magazine, p. 120.

in text citation : (Sahal, 2014) 


\section{Research report}

Fisher, B. S., Cullen, F. T., \& Turner, M. G. (2000). The Sexual Victimization of College Women. Research Report.

in text citation : (Fisher, Cullen, Turner, 2000)

\section{Monograph}

Routray, Bibhu Prasad (2013), National Security Decision-Making in India (RSIS Monograph No. 27). Singapura: Rajaratnam School of International Studies.

in text citation : (Routray, 2013)

\section{Proceeding article}

Sudibyakto, Hizbaron, D.R., \& Jati, R (Ed.) (2009), Proceeding International Seminar Disaster Theory, Research and Policy. International seminar held by Sekolah Pascasarjana, Universitas Gajahmada, Yogyakarta, 8-9 Desember 2009.

in text citation : (sudibyakto and Jati, 2009)

\section{Paper conference/seminar/symposium}

Janutama, Herman Sinung (2011). "Kraton dan Hubungan Antar Agama." Paper presented in Seminar Kraton dan Panatagama held by Center for the Study of Islam and Social Transformation (CISForm), Yogyakarta, 17 November.

in text citation :(Janutama, 2011)

\section{Online article in web}

Shiva, (2006, February). Bioethics: A Third World Issue. Native-web. Diperoleh dari http://www.nativeweb.org/ pages/legal/shiva.html

in text citation : (Shiva, 2006) 


\section{Online research report}

Kessy, S. S. A., \& Urio, F M. (2006). The contribution of microfinance institutions to poverty reduction in Tanzania (Research Report No. 06.3). Retrieved from Research on Poverty Alleviation website: http://www.repoa.or.tz/documents_storage/Publications/Reports/06.3_Kessy_and_ Urio.pcif

in text citation : (kessy and urion, 2006)

\section{Holy book}

Qur an, $2(25)$

In text citation : (Q. al-Baqarah 2:25).

\section{Encyclopaedia}

Graycar, Adam (1992). Social Welfare Policy. Dalam Mary Hawkesworth dan Maurice Kogan (Ed.), Encyclopedia of Government and Politics (Vol. 1). London: Routledge.

in text citation : (Graycar, 1992)

\section{Interview}

Sultan Hamengkubuwono X (interview, 2011, April 19)

in text citation: (Hamengkubuwono, 2011)

\section{Documentary film}

Steijlen, Fridus (2008). A Day in the Life of Indonesia [documentary film, 58 minutes]. Leiden: KITLV Press.

in text citation : (Steijlen, 2008) 
Vol. 4 No. 1, January - April 2019 